\title{
Transcriptomics of different tissues of blueberry and diversity analysis of rhizosphere fungi under cadmium stress
}

\author{
Shaopeng Chen ${ }^{1 *}$, QianQian Zhuang ${ }^{1}$, XiaoLei Chu ${ }^{2}$, ZhiXin Ju' ${ }^{1}$ Tao Dong ${ }^{1}$ and Yuan Ma ${ }^{1}$
}

\begin{abstract}
Blueberry (Vaccinium ssp.) is a perennial shrub belonging to the family Ericaceae, which is highly tolerant of acid soils and heavy metal pollution. In the present study, blueberry was subjected to cadmium (Cd) stress in simulated pot culture. The transcriptomics and rhizosphere fungal diversity of blueberry were analyzed, and the iron (Fe), manganese (Mn), copper (Cu), zinc (Zn) and cadmium (Cd) content of blueberry tissues, soil and DGT was determined. A correlation analysis was also performed. A total of 84374 annotated genes were identified in the root, stem, leaf and fruit tissue of blueberry, of which 3370 were DEGs, and in stem tissue, of which 2521 were DEGs. The annotation data showed that these DEGs were mainly concentrated in a series of metabolic pathways related to signal transduction, defense and the plant-pathogen response. Blueberry transferred excess $\mathrm{Cd}$ from the root to the stem for storage, and the highest levels of $\mathrm{Cd}$ were found in stem tissue, consistent with the results of transcriptome analysis, while the lowest $\mathrm{Cd}$ concentration occurred in the fruit, $\mathrm{Cd}$ also inhibited the absorption of other metal elements by blueberry. A series of genes related to $C d$ regulation were screened by analyzing the correlation between heavy metal content and transcriptome results. The roots of blueberry rely on mycorrhiza to absorb nutrients from the soil. The presence of $\mathrm{Cd}$ has a significant effect on the microbial community composition of the blueberry rhizosphere. The fungal family Coniochaetaceae, which is extremely extremelytolerant, has gradually become the dominant population. The results of this study increase our understanding of the plant regulation mechanism for heavy metals, and suggest potential methods of soil remediation using blueberry.
\end{abstract}

Keywords: Blueberry, Cadmium, Transcriptomics, Microbial diversity, Heavy metal absorption

\section{Introduction}

Cadmium $(\mathrm{Cd})$ is a toxic heavy metal that accumulates in soil as a result of air and water circulation, and acts on the human body through the food chain. The accumulation of $\mathrm{Cd}$ in the human body causes severe toxic reactions [1]. The pollution area and toxic effects of $\mathrm{Cd}$ have a serious impact worldwide [2]. At present, Cd pollution of agricultural soils in China is very extensive, and has

\footnotetext{
*Correspondence: 408436788@qq.com

${ }^{1}$ College of Agriculture, Jilin Agricultural Science and Technology University, Jilin 132101, PR China

Full list of author information is available at the end of the article
}

caused major environmental problems [3]. Moreover, $\mathrm{Cd}$ and its compounds are readily soluble in water under acidic conditions. However, the dissolution rate of $\mathrm{Cd}$ in neutral to alkaline soil is very low [4]. Therefore, how to efficiently remove $\mathrm{Cd}$ in acid-contaminated soil is a very important topic $[5,6]$. The use of hyperaccumulators for remediation of contaminated soil is highly efficient and protects the environment, and has therefore attracted increasing attention. Plant species such as Rorippa globulosa, Solanum nigrum, Sedum alfredii, Viola baoshanensis and Pteris vittata can enrich Cd and some other heavy metals in soil [7]. However, the use of plants for soil 
remediation is also associated with slow growth rates, resulting in economic losses.

Blueberry (Vaccinium ssp.) is a perennial shrub belonging to the family Ericaceae that thrives on acid soil. It was introduced and domesticated successfully in the early twentieth century. However, it is only within the last 20 years that, as the unique flavour and high nutritional value of this crop have led to growing demand for its production, its cultivation area has expanded rapidly worldwide, particularly in Europe, North America, South America and Asia, including China [8]. It is well documented in the literature that blueberry fruit is rich in anthocyanins, and contains among the highest antioxidant levels of any fruit [9]. Moderate intake can significantly reduce the risk of cardiovascular and cerebrovascular disease and type 2 diabetes mellitus, and provides some degree of neuroprotection [10]. However, a number of studies have highlighted a new potential application for this plant. Blueberry is a dominant tree species in acid soils polluted with heavy metal compounds $[11,12]$, to the extent that it is often used as an indicator species for monitoring local pollution with heavy metals $[13,14]$. Kandziora-Ciupa et al. studied the response of $V$. myrtillus (bilberry) to heavy metals in three contaminated sites in Finland. Their results showed that $V$. myrtillus could adapt to the polluted soil [15]. A large number of plants of $V$. angustifolium and $V$. myrtilloides grow around the ore smelters in Sudbury, Canada. Both species can tolerate heavy-metal-contaminated soil and grow well on it. It is of paramount importance that the levels of heavy metal pollutants $(\mathrm{Cu}$ and $\mathrm{Ni})$ in the fruits of these species do not exceed the internationally agreed safe values, so that they are safe for human consumption [16]. In the Majiang blueberry production area in China, Li et al. measured the heavy metal content of soil and fruit. Their results showed that although the heavy metal levels in soil exceeded the maximum safe value, the corresponding levels in fruit did not. Chen et al. studied blueberry plants that had been cultivated in Cd-contaminated soil, and found that the $\mathrm{Cd}$ content of the fruit was not significantly affected by soil pollution [17], which suggests a potential new role for this plant as a remediation species in acid soil contaminated with heavy metals.

The absorption and detoxification of heavy metals in plants are complex regulatory processes. Unnecessary heavy metals seriously impair morphological and structural development, inhibit physiological processes, cause oxidative stress reactions, and ultimately result in death of the plant [18-20]. Cotton (Gossypium hirsutum) can resist $\mathrm{Cd}$ toxicity by a combination of cell wall thickening, an increase in antioxidant activity and the formation of complexes with heavy metals under conditions of $\mathrm{Cd}$ stress, and there are also specific signal transduction pathways, such as the brassinosteroid and ethylene signalling pathways, in this species [21]. In response to $\mathrm{Cd}$ stress, ABC transporters, Zrt/IRT and transcription factors are significantly induced in the roots of Festuca arundinacea, mainly reflecting activity of the pathways related to glutathione metabolism, phenylpropanoid biosynthesis and nitrogen metabolism [22]. Compared with the high-Cd-accumulating type, there is a delay in transcriptional changes in response to $\mathrm{Cd}$ in the low-Cdaccumulating type. Cell wall biosynthesis and glutathione metabolism are involved in the $\mathrm{Cd}$ defense response of the high-Cd-accumulating type. Moreover, the expression of $\mathrm{Cd}$ transport genes has been found to differ between two types of Chinese cabbage [23]. In Kandelia obovata under $\mathrm{Cd}$ or $\mathrm{Zn}$ stress, three phenolic metabolism pathways are involved in the heavy metal tolerance mechanism, and the heavy metal content of the leaves is positively correlated with their total phenol content [24].

Heavy metals present in the soil not only affect the plants growing in it, but also have a significant impact on the microorganisms in the soil. In previous studies it has been reported that soil microorganisms are much more sensitive to heavy metal stress than are either soil animals or plants growing in the same soil [25]. Excessive amounts of heavy metals in the soil also lead to changes in the biomass and diversity of soil microorganisms [26]. A combination of plant root exudates and the microorganisms associated with the roots can enhance the plant's tolerance of the toxic effects of heavy metals [25]. It has been found that soil microorganisms can reduce the mobility and bioavailability of metals through the processes of biosorption and precipitation [27]. The degree of severity of heavy metal pollution also affects the composition of the microbial community. Under conditions of severe pollution, the dominant microbial population in rice roots is positively correlated with $\mathrm{Cd}$ concentration [28]. Blueberry has a small fibrous undeveloped root system, which forms mycorrhizal associations with mycorrhizal fungi that also interact with symbiotic bacteria and provide the necessary nutrients for the plant [29]. The mycorrhizae of Blueberry can help the plant to resist the adverse effects of environmental factors such as drought and low temperature [30, 31].

To date there have been only a few reports on the physiological effects of heavy metals on blueberry cultivation. Blueberry can reduce the toxic effects of heavy metals by regulating its own antioxidant stress response. The toxic effects are related to the type of heavy metal and the duration of exposure. It has also been found that the levels of nitrogen, phosphorus and potassium in blueberry are positively correlated with the plant's heavy metal content, and that the glutathione (GSH) content of blueberry decreases under excessive stress $[15,32]$. However, 
the mechanism of heavy metal tolerance, the relationship with tissue redistribution, and even the changes in mycorrhizal fungi in blueberry are unclear. Therefore, in order to explore the response of blueberry to heavy metals, as well as the changes in mycorrhizal fungi under $\mathrm{Cd}$ stress, there is a need to understand the internal regulation mechanism for heavy metals in this plant, and to explore the potential use of blueberry for remediation of acid soil that is contaminated with heavy metals.

\section{Test materials and methods}

\section{Test materials and pretreatment}

Vaccinium corymbosum 'Bluegold', a late-maturing variety of blueberry grown on the horticultural farm of Jilin Agricultural Science and Technology University, was used as the experimental material for this study. In May 2017, 2-year-old blueberry seedlings were planted in a non-woven pot $(50.0 \mathrm{~cm} \times 50.0 \mathrm{~cm} \times 50.0 \mathrm{~cm})$. The planting medium was peat soil, and the soil $\mathrm{pH}$ was adjusted to 5.0 with sulfur. Blueberry plants were normally maintained in the pot for two growth cycles to ensure that they developed up to the high-yield stage. On 1 June 2020, blueberry plants with the same rate of growth, normal pollination and fruit setting were selected for $\mathrm{Cd}$ stress testing. In order to avoid the interference of $\mathrm{Cl}^{-}$ ions with plant growth, the treatment group was treated with an aqueous solution of $\mathrm{CdSO}_{4}$ to give a soil $\mathrm{Cd}^{2+}$ concentration of $400 \mathrm{mg} / \mathrm{kg}$ (calculated on the basis of the weight of pure metal), and the control group (CK) was potted without $\mathrm{CdSO}_{4}$. Each treatment was repeated three times. After the potted plants had been treated, they were all maintained in full sunlight in a greenhouse to prevent leaching by rainwater. Management consisted of irrigation of each basin with $3.0 \mathrm{~L}$ of deionized water every 2 days, and the leachate under the basin was collected for reinjection. Blueberry fruits were harvested on 25 August 2020, and roots, stems, leaves and soil samples were collected on 30 September 2020. All tissue samples were washed with deionized water three times and dried in the shade. They were then frozen in liquid nitrogen and stored in aseptic bags at $-80^{\circ} \mathrm{C}$ in a freezer. After the blueberry plant roots had been dug up and excess soil removed from them, they were shaken in sterile self-sealing bags so that the remaining soil attached to the roots was separated out. The roots were then frozen in liquid nitrogen and stored in a freezer at $-80^{\circ} \mathrm{C}$.

\section{Construction of transcriptome database RNA extraction}

Total RNA was extracted from the roots, stems, leaves and fruits using the Total RNA Purification Kit, TRK1001 (LC Science, Houston, TX), and was then subjected to agarose gel electrophoresis prior to testing. The quality and concentration of samples was checked using the Agilent 2100 Bioanalyzer (Agilent, USA). The O.D. A260/280 was above $1.70-2.10$, and the concentration was between $0.03-0.23 \mu \mathrm{g} / \mu \mathrm{L}$.

\section{Database construction, sequencing and annotation}

Total RNA was extracted from roots, stems, leaves and fruits of the treatment group and the control group for transcriptome sequencing. The sequencing included three biological replicates, giving a total of 24 groups of samples. The sequencing work was undertaken by Hangzhou Lianchuan Bio Technologies Co., Ltd., and the NovaSeq 6000 System (Illumina, USA) was used for sequencing. In order to maximize the quality of data, the original data were filtered. The content of filtering includes: removing the splice sequence from the sequencing reads; The sequencing reads were scanned by window method, and the default scanning window was $6 \mathrm{bp}$, When the average quality value in the window is less than 20, the part of the read from the beginning of the window to the end of 3 is cut off; Poly-A / T was removed; The truncated sequences less than $100 \mathrm{bp}$ in length were removed; Remove the truncated sequence with more than $5 \% \mathrm{~N}$ content The sequence quality, including effective sequencing quantity, Q20, q30 and GC content, was estimated using FastQC (http://www. bioinformatics.babraham.ac.uk/projects/fastqc/). De novo assembly of the transcriptome was performed with Trinity 2.4.0. All the newly assembled gene sequences (UniGene) were compared with the NR database (http:// www.ncbi.nlm.nih.gov/), GO (http://www.geneontolo gy.org), SwissProt (http://www.expasy.ch/sprot/), KEGG (http://www.genome.jp/kegg/), Pfam(http://pfam.xfam. org/) and EggNOG (http://eggnogdb.embl.de/) Compare and annotate the database.

\section{Differentially expressed Unigene analysis}

Salmon was used to perform expression level for Unigenes by calculating TPM. The differentially expressed Unigenes were selected with log2 (fold change) $>1$ or $\log 2$ (fold change) $<-1$ and with statistical significance $(p$ value $<0.05)$ by $R$ package edgeR [33-35].

\section{Fluorescence-based quantitative PCR}

The transcription levels of differentially expressed genes (DEGs) in roots, stems, leaves and fruits were determined by quantitative real-time PCR (qRT PCR), which was performed using SYBR Premix Ex Taq (Tli RNase $\mathrm{H}$ plus, Takara). cDNA (20 times diluted) was used as the template for qRT PCR. The operation process and reaction conditions were as described in the manufacturer's instructions, and the qRT PCR was repeated three times. The relative gene expression was calculated using 
the comparative CT $\left({ }^{-\Delta \Delta} \mathrm{CT}\right)$ method. The gene-specific primers for qRT PCR were designed using Primer Express Software v3.0, and the internal reference gene was blueberry glyceraldehyde-3-phosphate dehydrogenase (GAPDH, NCBI accession number: AY123769.1). The qRT PCR specific primers and internal reference primers are listed in Table 1.

\section{Determination of heavy metal content}

The $\mathrm{Cd}, \mathrm{Mn}, \mathrm{Cu}, \mathrm{Fe}$ and $\mathrm{Zn}$ content of roots, stems, leaves and fruits was determined by inductively coupled plasma mass spectrometry (ICP-MS). The specific operation mode was as described in GB 5009.268-2016 National Food Safety Standard: Determination of Multi Elements in Food. The microwave digestion method was

Table 1 Specific primers and internal reference primers

\begin{tabular}{|c|c|c|}
\hline Primer name & Sequence $\left(5^{\prime}-3^{\prime}\right)$ & Description \\
\hline DN28053_c0_g3-F & TGGGCTCTATGTAAATCTCCGTAT & Root DN28053 c0 g3 qRT-PCR Primer \\
\hline DN28053_c0_g3-R & CAACTTGCTTATTCCACCATACTCAT & Root DN28053 c0 g3 qRT-PCR Primer \\
\hline DN43627_c1_g2-F & GGGATTTGTTTAGGGTAGTTGAAGG & Root DN43627 c1 g2 qRT-PCR Primer \\
\hline DN43627_c1_g2-R & TGAGACCAATGTCCCAACCACT & Root DN43627 c1 g2 qRT-PCR Primer \\
\hline DN32241_c0_g1-F & CAAAGCCTCCTATGGGTCTGA & Root DN32241 c0 g1 qRT-PCR Primer \\
\hline DN32241_C0_g1-R & TATGACCGTGGCAAGGTCTG & Root DN32241 c0 g1 qRT-PCR Primer \\
\hline DN21228_c0_g1-F & TTTCGGACATCCAAAGACAGC & Root DN21228 c0 g1 qRT-PCR Primer \\
\hline DN21228_c0_g1-R & GAAGAGTGCCTGTATGAGGGTTG & Root DN21228 c0 g1 qRT-PCR Primer \\
\hline DN28398_c1_g2-F & ATGAATGGAGGGCTTGGAGAA & Root DN28398 c1 g2 qRT-PCR Primer \\
\hline DN28398_c1_g2-R & CAGCCCAAGTCAGCAATGTTT & Root DN28398 c1 g2 qRT-PCR Primer \\
\hline DN29181_C0_g2-F & CGGGTCAGTTTACGAGCAGAA & Stem DN29181 c0 g2 qRT-PCR Primer \\
\hline DN29181_C0_g2-R & GCACATACGCCATCTTCTTCG & Stem DN29181 c0 g2 qRT-PCR Primer \\
\hline DN35069_c1_g1-F & GTGGACCCAAAGCAGCACAAG & Stem DN35069 c1 g1 qRT-PCR Primer \\
\hline DN35069_c1_g1-R & GCCAGGTTGGTAATCTGAGGG & Stem DN35069 cl g1 qRT-PCR Primer \\
\hline DN39782_c0_g2-F & GGTCGCTTTCCTCCACTCA & Stem DN39782 c0 g2 qRT-PCR Primer \\
\hline DN39782_C0_g2-R & ACGCCAAACTCAAAGCCAGA & Stem DN39782 c0 g2 qRT-PCR Primer \\
\hline DN35079_c1_g3-F & CCCCACATTAGCGGTGTTCAA & Stem DN35079 c1 g3 qRT-PCR Primer \\
\hline DN35079_c1_g3-R & CTTCACGTCCAAAACACTTAGCTTC & Stem DN35079 c1 g3 qRT-PCR Primer \\
\hline DN36954_c0_g2-F & GTGCCCTAACTTTGGGATGACT & Stem DN36954 c0 g2 qRT-PCR Primer \\
\hline DN36954_c0_g2-R & CATCATTCCTTTCCAAGCACC & Stem DN36954 c0 g2 qRT-PCR Primer \\
\hline DN41993_C0_g1-F & CTACGACGCACTTGCCTCTGT & Leaf DN41993 c0 g1 qRT-PCR Primer \\
\hline DN41993_C0_g1-R & GGGCAAACTGAAGAGGCACAT & Leaf DN41993 c0 g1 qRT-PCR Primer \\
\hline DN30310_c0_g3-F & TAGTTTCCGTTTGGGTATGCG & Leaf DN30310 c0 g3 qRT-PCR Primer \\
\hline DN30310_c0_g3-R & TTGTGCTCAGCCTGGAATACG & Leaf DN30310 c0 g3 qRT-PCR Primer \\
\hline DN44211_c1_g3-F & ATGAAGTATGGCGGCTGGAAA & Leaf DN44211 c1 g3 qRT-PCR Primer \\
\hline DN44211_c1_g3-R & TGTTCTACGGTAAACTCCCACATC & Leaf DN44211 c1 g3 qRT-PCR Primer \\
\hline DN26309_c0_g1-F & CGTCGGGAATGATTGGAGTTT & Leaf DN26309 c0 g1 qRT-PCR Primer \\
\hline DN26309_c0_g1-R & TCTTCTTTCAGCCCGTAATCG & Leaf DN26309 c0 g1 qRT-PCR Primer \\
\hline DN42843_C0_g4-F & TTTGAGTGATAAGATGCCGTTCC & Leaf DN42843 c0 g4 qRT-PCR Primer \\
\hline DN42843_c0_g4-R & TCCAGAGTGGTTCCGAGTAGGT & Leaf DN42843 c0 g4 qRT-PCR Primer \\
\hline DN29906_c1_g1-F & GCCGCTGCTGGTTCCATTTA & Fruit DN29906 c1 g1 qRT-PCR Primer \\
\hline DN29906_c1_g1-R & GTTGCCAAATGCCCAATACCC & Fruit DN29906 c1 g1 qRT-PCR Primer \\
\hline DN30439_c2_g2-F & GTGACCCTCCAAACCTCCATT & Fruit DN30439 c2 g2 qRT-PCR Primer \\
\hline DN30439_c2_g2-R & GGCAGTTCTTGAGCCCTTGAT & Fruit DN30439 c2 g2 qRT-PCR Primer \\
\hline DN44638_c1_g4-F & CGTCTCCTCAACTGCCCTCTT & Fruit DN44638 c1 g4 qRT-PCR Primer \\
\hline DN44638_c1_g4-R & CTCCAGCAATGGCACATCTTT & Fruit DN44638 c1 g4 qRT-PCR Primer \\
\hline DN21435_c0_g1-F & CTTGACACCGAGGCTGCTTAT & Fruit DN21435 c0 g1 qRT-PCR Primer \\
\hline DN21435_C0_g1-R & TTGATGACCTGAAACGCCACA & Fruit DN21435 c0 g1 qRT-PCR Primer \\
\hline DN43035_c0_g1-F & TTTGAATAAGGGTGATTTGAGTGTC & Fruit DN43035 c0 g1 qRT-PCR Primer \\
\hline DN43035_c0_g1-R & TTCAACAACGAAGCCAATACAA & Fruit DN43035 c0 g1 qRT-PCR Primer \\
\hline GAPDH-F & CATCCACTCTATCACCGCAACAC & Reference gene qRT-PCR Primer \\
\hline GAPDH-R & GCAGGCAACACCTTACCAACAG & Reference gene qRT-PCR Primer \\
\hline
\end{tabular}


used to measure the $\mathrm{Cd}, \mathrm{Mn}, \mathrm{Cu}, \mathrm{Fe}$ and $\mathrm{Zn}$ content in soil according to the specific operation mode described in HJ 832-2017 Microwave Digestion Method for Total Metal Elements in Soil and Sediment.

\section{DGT (diffusive gradients in thin films) technology}

DGT technology was used to simulate the absorption of heavy metals in soil by plant roots. A $200 \mathrm{~g}$ sample of soil taken from the middle of the basin was dried at $85^{\circ} \mathrm{C}$ to constant weight, and was then passed through a $2 \mathrm{~mm}$ sieve to remove large particles. Deionized water was added to achieve $70 \%$ of maximum field capacity, and was mixed well with the soil. The soil was sealed with plastic film and placed in an incubator at $25^{\circ} \mathrm{C}$ for $48 \mathrm{~h}$ to balance the soil. The balanced soil was then evenly smeared into the inner cavity of the DGT ring to ensure the same amount of soil was loaded into all of the DGT cavities. After loading, the soil was placed in an incubator at $25^{\circ} \mathrm{C}$ for enrichment for $24 \mathrm{~h}$ before the recovery device. After the soil had been cleaned with deionized water the fixed membrane was removed, the front of the membrane was rolled into a $2.0 \mathrm{~mL}$ centrifuge tube containing $1.8 \mathrm{~mL}$ of

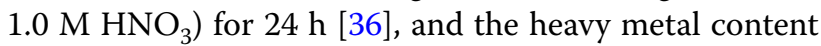
was determined at the end of the extraction. Colorimetric analysis was used to determine the ferrous iron $\left(\mathrm{Fe}^{2+}\right)$ content [37], and ICP-MS was used to determine the levels of the other heavy metals.

\section{Diversity of fungi in the rhizosphere}

Fungal DNA was extracted from the rhizosphere of blueberry using the Total TopTaq DNA Polymerase Kit (TransGen Biotech Co., Ltd, China), and total fungal DNA was then subjected to agarose gel electrophoresis prior to testing. The quality and concentration of DNA samples were checked using the NanoDrop 2000 spectrophotometer. The concentration was higher than $20 \mathrm{ng} / \mathrm{L}$, the total amount was more than $500 \mathrm{ng}$, and OD260/280 was in the range of $1.8 \sim 2.0$. DNA samples were stored in a freezer at $-80^{\circ} \mathrm{C}$. After the total DNA of rhizosphere fungi had been extracted, the primers were designed according to the conserved region, and the sequencing connector was added at the end of the primers. After PCR amplification, the single band was cut and recovered for library quality inspection. The library was then sequenced using the Illumina MiSeq platform and a $2 \times 250$ bp paired-end sequencing strategy. For operational taxonomic unit (OTU) analysis and species annotation, UCLUST in QIIME2 (version 1.8.0) software was used [38, 39]. After filtering, de-noising, splicing and removal of chimeras, OTUs were clustered at a similarity threshold of $97 \%$ and compared with the fungal taxonomy database (UNITE, http://unite.ut.ee/ index.php). Finally, taxonomic annotation at the level of phylum, class, order, family, genus and species was performed. The species annotation, alpha diversity, Simpson and Shannon indices were analyzed using krona, Mothur v.1.30 (http://www.mothur.org/).

\section{Data analysis and mapping}

SPSS 22.0 was used for data analysis, and Excel and R were used to plot the data.

\section{Results}

Transcriptome database analysis Gene assembly data

A total of 24 blueberry cDNA libraries were sequenced using the NovaSeq 6000 platform. After filtering and assembling the original data (Table 2) a total of 84374 genes were obtained, with a GC content of $42.02 \%$. The shortest gene sequence was $201 \mathrm{bp}$, and the longest sequence was $15879 \mathrm{bp}$, with an average length of $491 \mathrm{bp}$ and N50 length of $1473 \mathrm{bp}$. This indicates that the sequencing quality meets the requirements and can be used for subsequent analysis.

\section{Gene annotation data}

A total of 84374 genes were annotated, and the results are shown in Table 3.

\section{Differential expression of genes}

The DEGs in different tissues of blueberry that had been treated with $\mathrm{Cd}$ are shown in Fig. 1. There were 3370 DEGs in root, stem, leaf and fruit tissue $(P<0.05)$, of which 2521 DEGs (1644 up-regulated genes and 877 down-regulated genes) were present in stem tissue (representing $74.81 \%$ of the total). There were 360 (10.68\%) DEGs in fruits, 305 (9.05\%) DEGs in leaves, and 184 (5.46\%) DEGs in roots.

\section{Verification of differentially expressed genes by $q R T P C R$}

In order to verify the reliability and reproducibility of RNA-Seq, 20 genes were randomly selected from

Table 2 Gene assembly data

\begin{tabular}{llllllll}
\hline Index & All & GC\% & Min Length & Median Length & Max Length & Total Assembled Bases & N50 \\
\hline Transcript & 271,500 & 42.08 & 201 & 632 & 15,879 & $257,120,425$ & 1465 \\
Gene & 84,374 & 42.02 & 201 & 491 & 15,879 & $72,538,271$ & 1473 \\
\hline
\end{tabular}


Table 3 Gene annotation data

\begin{tabular}{lll}
\hline Database & Number & Ratio (\%) \\
\hline All & 84,374 & 100 \\
GO & 31,729 & 37.61 \\
KEGG & 25,247 & 29.92 \\
Pfam & 28,741 & 34.06 \\
SwissProt & 25,692 & 30.45 \\
EggNOG & 36,070 & 42.75 \\
NR & 37,714 & 44.7 \\
\hline
\end{tabular}

blueberry root, stem, leaf and fruit tissue for qRT PCR detection, and the expression of these genes in different tissues under $\mathrm{Cd}$ stress was analyzed (Fig. 2). They included functional genes, transporters, protective enzymes and transcription factors. The expression of 20 differential genes was consistent with that of RNASeq, with the exception of $\operatorname{dn} 30310 \operatorname{cog} 3$ (shown in red), which indicated that the sequencing results were reliable.

\section{Gene ontology (GO) enrichment analysis}

Under $\mathrm{Cd}^{2+}$ stress, the GO enrichment results for DEGs varied in different tissues of blueberry (Fig. 3), and only the top $15 P$-values are shown in Fig. 3. A total of 96 significant GO-rich sub-items were obtained in root tissue, which were mainly concentrated in the cell wall, extracellular region and ectoplasm. In addition, the enrichment factors of cotransporter, oxalate metabolism and oxalate decarboxylase process were higher. A total of 226 significant GO-rich sub-items were obtained in stem tissue, which were mainly concentrated in the plasma membrane, and were also enriched in the defense reaction, abscisic acid reaction, protein phosphorylation, xyloglucosan and signal transduction pathways. A total of 107 significant GO-rich sub-items were obtained in leaf tissue, which were mainly concentrated in the cell membrane, extracellular region and plastids. The biosynthesis of secondary metabolites, cell wall tissue and oxidoreductase activity also played an important role. A total of 355 significant GO-rich sub-items were obtained in fruit tissue, which were mainly concentrated in the cell membrane and extracellular region. There were also many differences in the cell wall and in oxidoreductase activity.

\section{KEGG enrichment analysis}

Under Cd stress, the KEGG enrichment results varied for different tissues of blueberry (Fig. 4). In terms of the number of differential genes, enrichment factor and $P$-value, the differential expression of the KEGG pathway in blueberry roots mainly involves sphingolipid metabolism, glycosphingolipid biosynthesis and glycosaminoglycan degradation and other processes related to the cell membrane and the cell wall, and the degradation and metabolism of lactose, amino sugars, nucleotide sugars and other glycans. In addition, it is associated with phenylpropanoid biosynthesis, flavonoid biosynthesis and RNA transport. There were also differences in metabolic processes such as ABC transport and plant hormone signal transduction. The difference in the KEGG pathway in blueberry stems was mainly concentrated in the plant-pathogen interaction pathway, and the difference in the plant hormone signal transduction and MAPK signal transduction pathways also reached a significant level. In blueberry leaves, the KEGG pathway was mainly expressed in

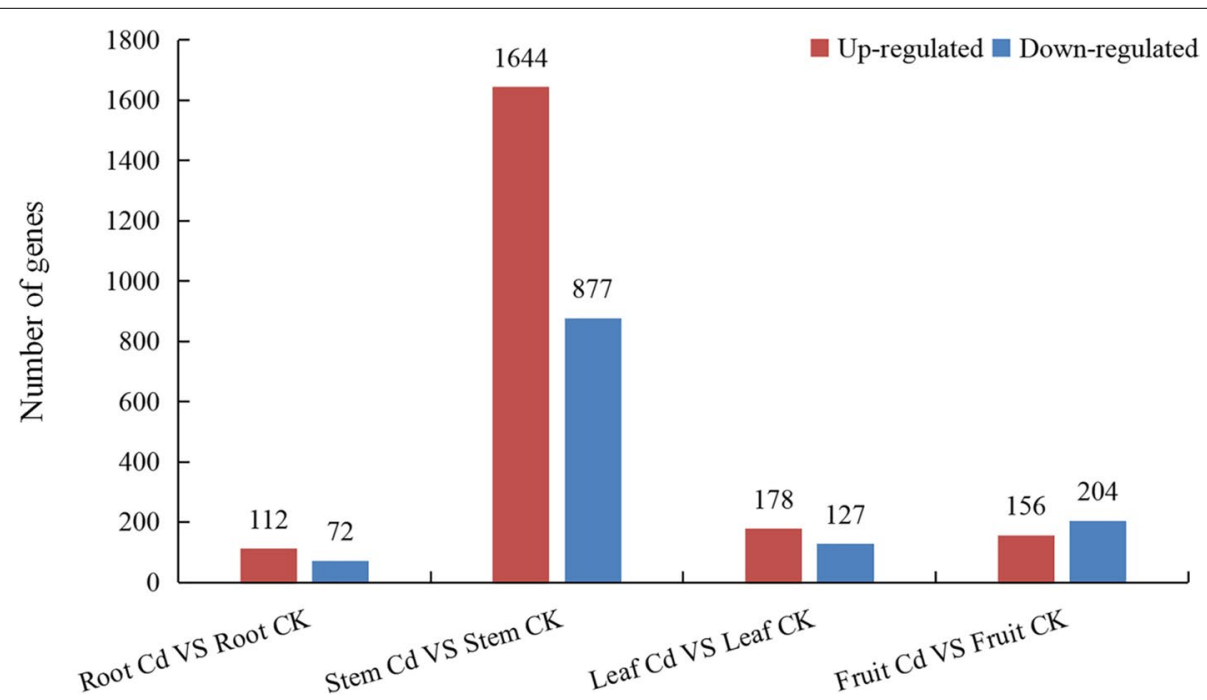

Fig. 1 Differentially expressed genes in different tissues of blueberry 

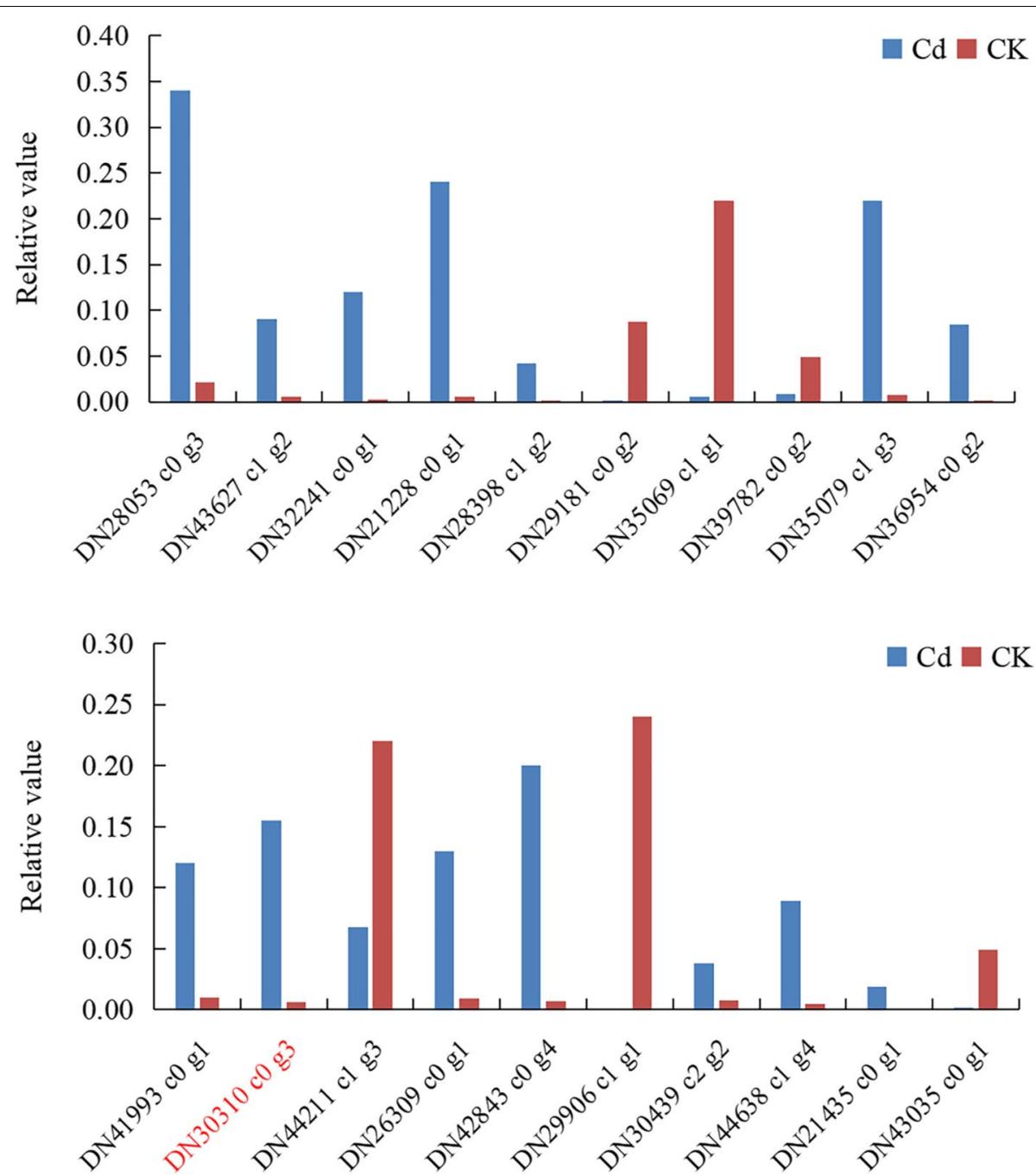

Fig. 2 The 20 differential genes that were verified by qRT-PCR

photosynthesis, followed by plant hormone signal transduction and oxidative phosphorylation. The differentially expressed KEGG pathways in blueberry fruits were mainly involved in the biosynthesis of melamine, piperidine and pyridine alkaloids, thiometabolism, flavone and flavonol biosynthesis, $\mathrm{ABC}$ transport and purine metabolism.

\section{Heavy metal content in different tissues}

Under Cd stress, the absorption of heavy metals by blueberry was significantly affected. It can be seen from Fig. 5A that $\mathrm{Mn}$ accumulated mainly in the root and stem of blueberry. Compared with the control group, the $\mathrm{Mn}$ content of root tissue in the treatment group was unaffected by $\mathrm{Cd}$ stress, and the $\mathrm{Mn}$ content of stem, leaf and fruit tissues decreased. The Mn content of leaf and fruit tissue in the treatment group was significantly different from that in the control group. The concentration of $\mathrm{Mn}$ was highest in the stem, where it exceeded Mn levels in the soil. Fe was the most abundant mineral element in the soil (Fig. 5b), and was mainly accumulated in the roots of blueberry. Under $\mathrm{Cd}$ stress, the Fe content of roots, stems, leaves and fruits decreased, and the Fe content of root tissue was significantly different compared with the control. The $\mathrm{Cu}$ content of blueberry tissues was much lower than the soil $\mathrm{Cu}$ content (Fig. 5C). Cd stress had no significant effect on the $\mathrm{Cu}$ content of blueberry tissues. The $\mathrm{Cu}$ content of root, stem and leaf tissue in the treatment group was significantly different from that in the control, but there was no significant difference in the $\mathrm{Cu}$ content of fruit tissue. The root system of blueberry has a significant 


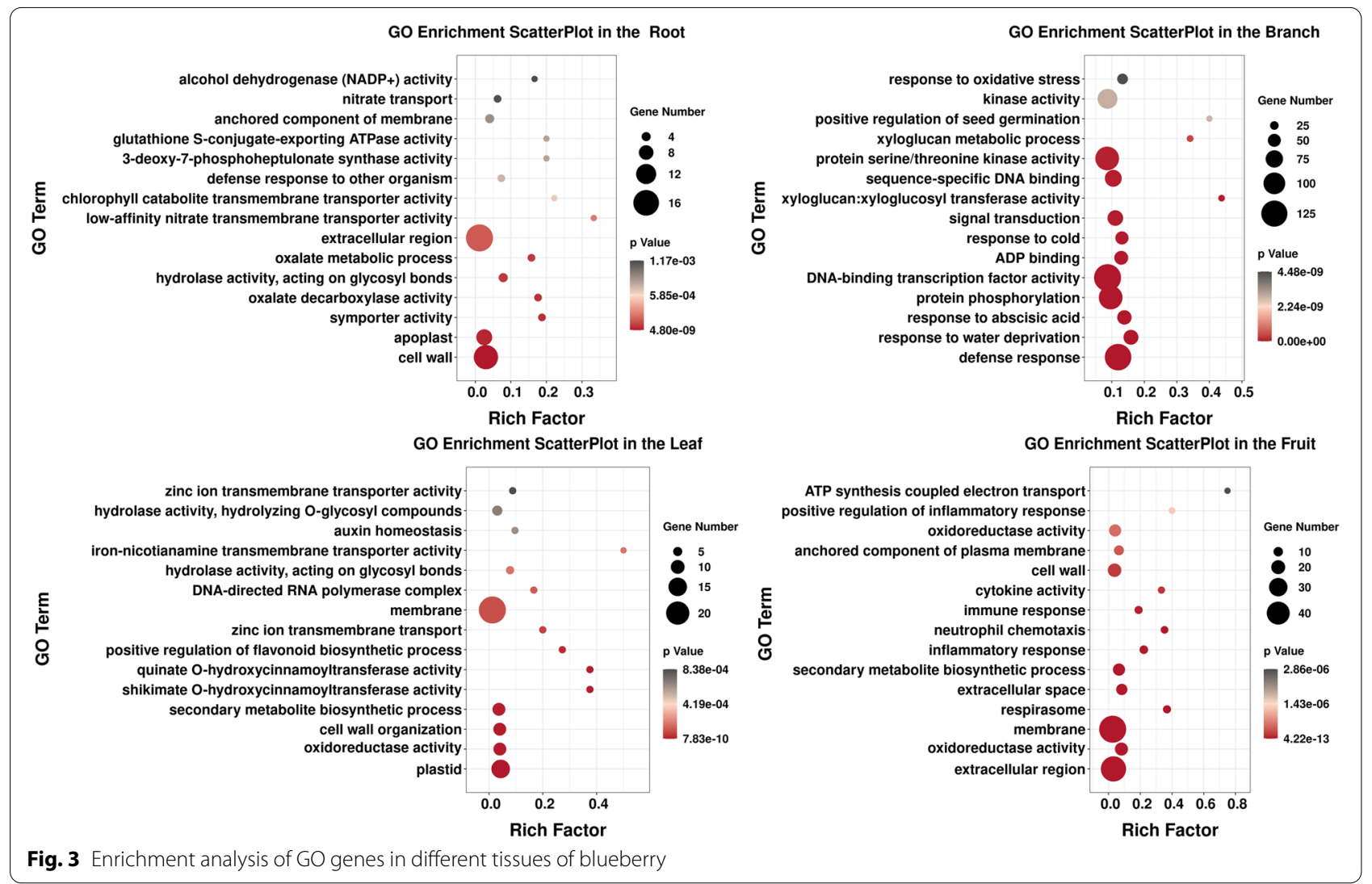

enrichment effect with regard to $\mathrm{Zn}$ (Fig. 5d), and high concentrations of $\mathrm{Zn}$ can accumulate in the root tissue. Under Cd stress, the $\mathrm{Zn}$ content of root and leaf tissue decreased significantly, whereas the $\mathrm{Zn}$ content of stem tissue increased. There was no significant difference in the $\mathrm{Zn}$ content of fruit tissue between the treatment and control groups.

$\mathrm{Cd}$ is a non-essential element in plants, and under conditions of $\mathrm{Cd}$ stress the extent to which it accumulated in root, stem, leaf and fruit tissue of blueberry varied (Fig. 5e). It mainly accumulated in the stems and roots, and the highest levels were found in the stems, followed by the leaves. Compared with the control, there was a highly significant difference in the Cd content of roots, stems and leaves in the treatment group, but a much smaller difference in the $\mathrm{Cd}$ content of fruits. The total $\mathrm{Cd}$ content of roots, stems, leaves and fruits did not exceed soil levels.

DGT is a passive soil sampling technology that simulates the process of passive absorption of mineral elements by plant roots. It can be seen from Fig. $5 \mathrm{~F}$ that $\mathrm{Cd}$ showed the highest rate of absorption by DGT, followed by Fe. Under Cd stress, there is a very significant increase in absorption of $\mathrm{Mn}$ and $\mathrm{Zn}$ compared with the control.
$\mathrm{Cu}$ showed the lowest rate of passive absorption, and $\mathrm{Cd}$ impaired the absorption of $\mathrm{Cu}$ by DGT.

\section{Correlation analysis of heavy metal content and DEGs}

The results of the correlation analysis of heavy metal content and DEGs in different tissues are presented in Table 4 (only the top 10 genes in each tissue are shown), and $R \geq 0.8$ and $P \leq 0.05$ were selected as the screening conditions. Of the 184 DEGs in blueberry root tissue, 37 DEGs were screened, including Cd30 (16.30\%), Cu4 (2.17\%), Zn2 (1.09\%) and Fe1 (0.54\%). Of these 37 DEGs, 16 DEGs were positively correlated and 21 DEGs were negatively correlated, and these genes included TRX2 and transcription factor myb26, among others. Of the 2521 DEGs in blueberry stem tissue, 1280 DEGs were screened, including Cd1230 (48.96\%), Zn13 (0.52\%), Fe5 (0.23\%), Mn5 (0.23\%) and $\mathrm{Cu} 2$ (0.09\%). Of these 1255 DEGs, 762 DEGs were positively correlated and 493 DEGs were negatively correlated. including calmodulin-dependent protein kinase and L-ascorbate oxidase. Of the 305 DEGs in blueberry leaf tissue, 181 DEGs were screened, including Cu109 (35.74\%), Cd48 (15.74\%) and Mn24 (7.87\%). Of these 181 DEGs, 100 DEGs were positively correlated and 81 DEGs were negatively correlated, including 


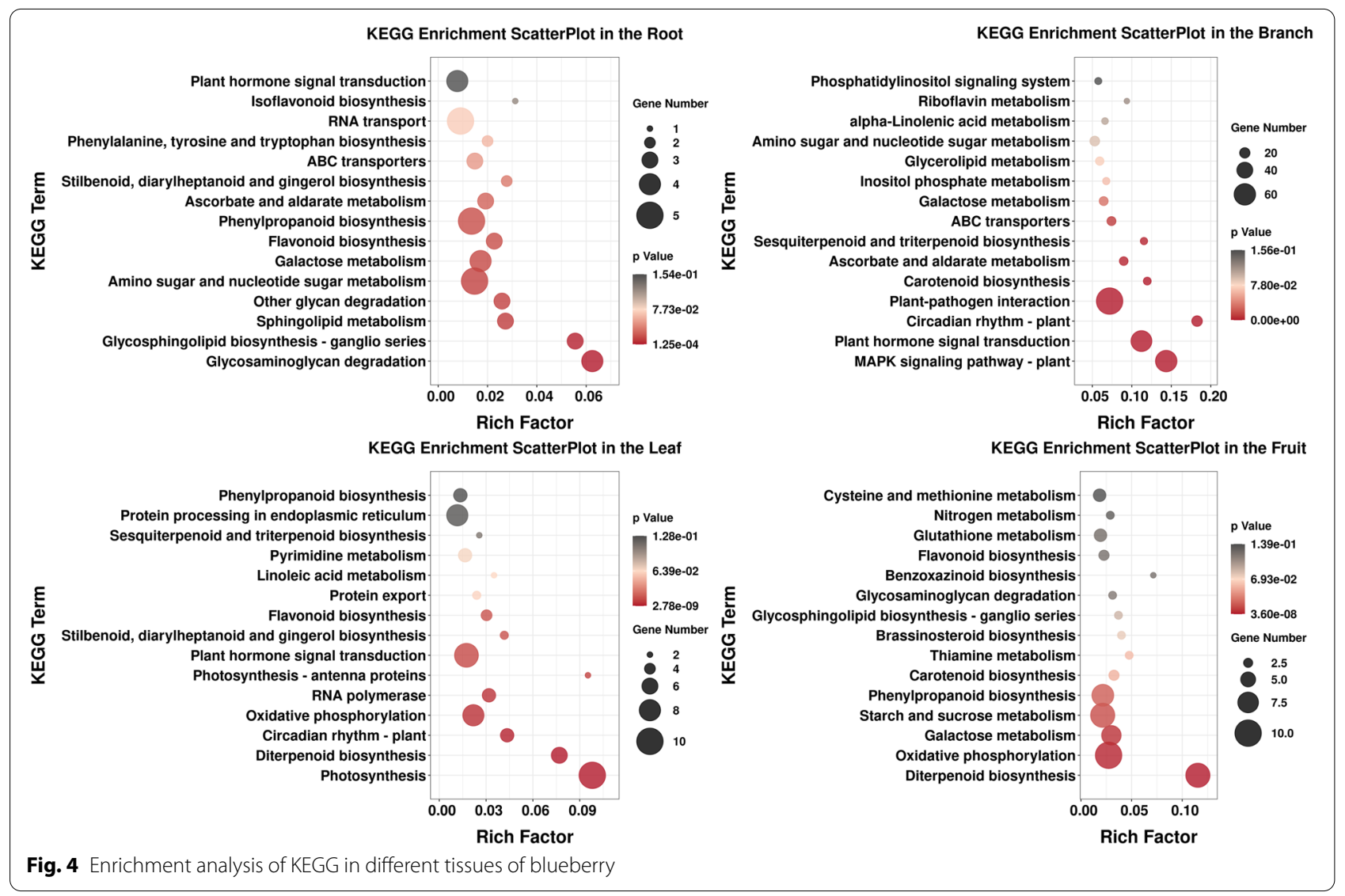

flavonoid 3-O-glucosyltransferase and peroxidase. Of the 360 DEGs in blueberry fruit tissue, 120 DEGs were screened, including Cu49 (13.61\%), mn35 (9.72\%), $\mathrm{Zn} 17$ (4.72\%), Fe12 (3.33\%) and Cd7 (1.94\%). Of these 120 DEGs, 82 DEGs were positively correlated and 38 DEGs were negatively correlated, including rhamnosyltransferase and heavy-metal-associated isolated plant protein.

\section{Fungal diversity in the rhizosphere \\ Quality analysis of sequencing data}

A total of 76848 original data were obtained in the treatment group $(\mathrm{M}-\mathrm{Cd})$ and 78259 original data were obtained in the control group (M-CK). After quality filtering, noise reduction, splicing and removal of chimeras, 64661 sequences were obtained in $\mathrm{M}-\mathrm{Cd}$ and 67148 sequences were obtained in $\mathrm{M}-\mathrm{CK}$, accounting for 84.28 and $86.03 \%$ of the original sequences, respectively. For M-Cd and M-CK, 93.66 and $94.82 \%$ of the sequences, respectively, were $245-259$ bp in length see Table 5 for detailed data.

\section{Taxonomic statistical analysis}

According to the taxonomic statistics, M-Cd includes the annotated fungi, which are divided into 6 phyla, 15 classes, 31 orders, 55 families and 69 genera, with a total of 190 species. M-CK included 141 species of fungi, which were classified into 8 phyla, 14 classes, 34 orders, 44 families and 57 genera. M-Cd was stronger than M-CK with regard to family, genus and species classification, but weaker than M-CK with regard to phylum and order. The labeled M-Cd and M-CK samples included 67 common species at the level of species classification.

\section{Relative species richness}

In order to simplify the presentation of the results, only the top 10 species of abundance level are shown, and the other species are combined into other, unclassified and unallocated species to represent the species that have not been annotated at this taxonomic level (Fig. 6) [40]. According to the classification method of Zhu et al., dominant microflora was defined as a relative abundance higher than $10 \%$, and rare microflora was defined as a relative abundance of less than 

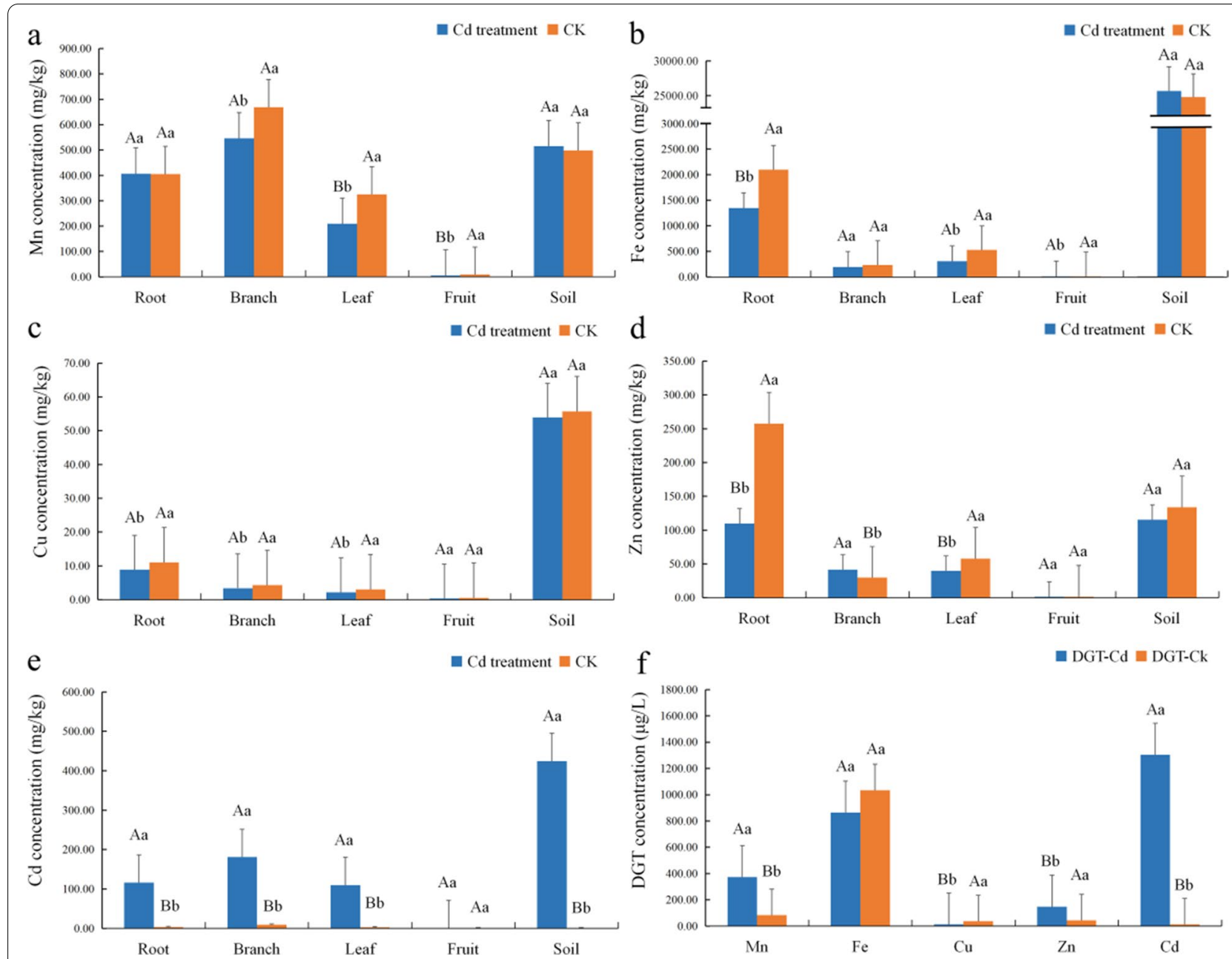

Fig. 5 Heavy metal content of different tissues and DGT concentration in blueberry

$0.01 \%$. In order to better screen the differences in species between the two groups, $P<0.05$ was used as the screening threshold of significant difference. At the phylum level, Ascomycota was the dominant microflora of M-Cd and M-CK, with richness index values of 0.9080 and 0.8039 , respectively. Basidiomycota was also the dominant microflora of M-CK (Fig. 6a). At the class level, the dominant microflora of $\mathrm{M}-\mathrm{Cd}$ and $\mathrm{M}-\mathrm{CK}$ was Eurotiomycetes, the dominant microflora of $\mathrm{M}-\mathrm{Cd}$ was Sordariomycetes, and the dominant microflora of M-CK included Leotiomycetes, Agaricomycetes and Archaeorhizomycetes. At the phylum level, although Tremellomycetes was not the dominant microflora of $\mathrm{M}-\mathrm{Cd}$ and $\mathrm{M}-\mathrm{CK}$, the richness index of $\mathrm{M}-\mathrm{Cd}$ was significantly different from that of M-CK (Fig. 6). At the order level, the dominant microflora of M-Cd consisted of Eurotiales and Coniochaetales, whereas the dominant microflora of $\mathrm{M}-\mathrm{CK}$ included Eurotiales,
Helotiales, Archaeorhizomycetes and Sebacinales, and the Archaeorhizomycetes richness index of M-CK was significantly higher than that of M-Cd (Fig. 6c). At the family level, the dominant microflora of $\mathrm{M}-\mathrm{Cd}$ and $\mathrm{M}-\mathrm{CK}$ was Aspergillaceae, and the dominant microflora of M-Cd was Coniochaetaceae (Fig. 6D). At the genus level, the dominant M-CK microflora only included Hamigera, but the dominant $\mathrm{M}-\mathrm{Cd}$ microflora included Hamigera, Coniochaeta and Penicillium (Fig. 6e). At the species level, Coniochaeta fodinicola was the only dominant member of the microflora in $\mathrm{M}-\mathrm{Cd}$, but the richness index of Talaromyces helicus in $\mathrm{M}-\mathrm{Cd}$ was significantly different from that in M-CK, and the richness index of Penicillium nepalense in $\mathrm{M}-\mathrm{Cd}$ was significantly different from that in M-CK (Fig. 6F). It should be noted that there were significant differences in the richness of some species in $\mathrm{M}-\mathrm{Cd}$ and $\mathrm{M}-\mathrm{CK}$ at each 
Table 4 Correlation analysis of heavy metal content and DEGs in different tissues

\begin{tabular}{|c|c|c|c|c|c|}
\hline Tissue & Gene_ID & $\begin{array}{l}\text { Related } \\
\text { heavy } \\
\text { metals }\end{array}$ & Length (bp) & Annotation & Species \\
\hline \multirow[t]{10}{*}{ Root } & DN28710_c0_g3+ & $\mathrm{Cd}$ & 700 & Thioredoxin-like & Actinidia chinensis \\
\hline & DN29606_C1_g1+ & $\mathrm{Cd}$ & 902 & $\begin{array}{l}\text { LOW-QUALITY PROTEIN: probable LRR receptor-like serine/threo- } \\
\text { nine-protein kinase At1g56130 }\end{array}$ & Herrania umbratica \\
\hline & DN31138_c0_g2- & $\mathrm{Zn}$ & 2017 & Butyrate-CoA ligase AAE11, peroxisomal-like & Actinidia chinensis \\
\hline & DN24062_c1_g1- & $\mathrm{Cd}$ & 1271 & PREDICTED: receptor-like protein 12 isoform $\times 2$ & Juglans regia \\
\hline & DN23316_c1_g6- & $\mathrm{Cd}$ & 828 & F-box/kelch protein & Camellia sinensis \\
\hline & DN44639_c0_g3+ & $\mathrm{Cd}$ & 1244 & Separase & Actinidia chinensis \\
\hline & DN31795_c0_g1+ & $\mathrm{Fe}$ & 651 & Hypothetical protein TanjilG_03599 & Lupinus angustifolius \\
\hline & DN41780_c0_g1- & $\mathrm{Cd}$ & 2666 & Zinc finger protein-like & Actinidia chinensis \\
\hline & DN38676_c0_g5- & $\mathrm{Cd}$ & 1462 & Transcription factor MYB26 & Vaccinium corymbosum \\
\hline & DN43227_c2_g4- & $\mathrm{Cd}$ & 1237 & LOB domain-containing protein & Actinidia chinensis \\
\hline \multirow[t]{10}{*}{ Stem } & DN31674_c0_g1+ & $\mathrm{Cd}$ & 2880 & Glutaredoxin-like & Actinidia chinensis \\
\hline & DN33390_c0_g2+ & $\mathrm{Cd}$ & 1474 & Reverse transcriptase zinc-binding domain-containing protein & Artemisia annua \\
\hline & DN30630_c0_g3 + & $\mathrm{Cd}$ & 990 & $\begin{array}{l}\text { PREDICTED: putative disease resistance RPP13-like protein } 1 \\
\text { isoform X1 }\end{array}$ & Vitis vinifera \\
\hline & DN26228_c0_g4+ & $\mathrm{Cd}$ & 1273 & Hypothetical protein Ahy_B03g066511 isoform B & Arachis hypogaea \\
\hline & DN22052_c0_g1- & $\mathrm{Cd}$ & 652 & $\begin{array}{l}\text { Calcium/calmodulin-dependent/calcium-dependent protein } \\
\text { kinase }\end{array}$ & Trema orientale \\
\hline & DN45416_c0_g1+ & $\mathrm{Cd}$ & 2040 & L-ascorbate oxidase & Actinidia chinensis \\
\hline & DN29755_c1_g4- & $\mathrm{Cd}$ & 332 & Hypothetical protein MIMGU_mgv1a009490mg & Erythranthe guttata \\
\hline & DN23873_c1_g3- & $\mathrm{Cd}$ & 1168 & PREDICTED: NAC domain-containing protein 30 isoform X1 & Theobroma cacao \\
\hline & DN44665_c1_g1+ & $\mathrm{Cd}$ & 4363 & Galacturonosyltransferase & Actinidia chinensis \\
\hline & DN36060_c0_g2- & $\mathrm{Cd}$ & 1912 & Non-characterized protein LOC107434963 & Ziziphus jujuba \\
\hline \multirow[t]{10}{*}{ Leaf } & DN41610_c1_g2+ & $\mathrm{Cd}$ & 2467 & UDP-glucose: flavonoid 3-O-glucosyltransferase & Vaccinium corymbosum \\
\hline & DN33777_c2_g4+ & $\mathrm{Cu}$ & 2497 & RNA polymerase beta subunit & Vaccinium macrocarpon \\
\hline & DN29488_c0_g1 + & $\mathrm{Cu}$ & 2037 & $\mathrm{ABC}$ transporter $\mathrm{G}$ family member 5 -like & Actinidia chinensis \\
\hline & DN35515_c0_g2+ & $\mathrm{Cd}$ & 781 & Phosphoenolpyruvate carboxylase & Actinidia chinensis \\
\hline & DN23563_c0_g1+ & $\mathrm{Cd}$ & 563 & Glucan endo-1,3-beta-glucosidase & Actinidia chinensis \\
\hline & DN25577_c0_g2+ & $\mathrm{Cu}$ & 575 & Low-temperature-induced protein & Actinidia chinensis \\
\hline & DN23052_c0_g1 + & $\mathrm{Cd}$ & 1302 & Lon protease & Actinidia chinensis \\
\hline & DN35869_c0_g2- & $\mathrm{Cu}$ & 1327 & Peroxidase & Actinidia chinensis \\
\hline & DN24887_c0_g6- & $\mathrm{Cu}$ & 1302 & F-box/kelch-repeat protein & Actinidia chinensis \\
\hline & DN41993_c0_g1- & $\mathrm{Cu}$ & 1511 & Glucan endo-1,3-beta-glucosidase & Actinidia chinensis \\
\hline \multirow[t]{10}{*}{ Fruit } & DN41010_c1_g1+ & $\mathrm{Zn}$ & 1855 & UDP-rhamnose:rhamnosyltransferase & Actinidia chinensis \\
\hline & DN43002_c0_g4+ & $\mathrm{Mn}$ & 928 & Olel & Camellia oleifera \\
\hline & DN24275_c0_g4+ & Zn & 539 & Fatty acid desaturase & Parasponia andersonii \\
\hline & DN43823_c0_g1+ & $\mathrm{Mn}$ & 3530 & Receptor-like protein kinase & Actinidia chinensis \\
\hline & DN41309_C0_g1+ & $\mathrm{Cu}$ & 1318 & Late embryogenesis abundant protein D-34-like & Cucurbita moschata \\
\hline & DN22211_c0_g1+ & $\mathrm{Zn}$ & 971 & BRASSINOSTEROID INSENSITIVE 1-associated receptor kinase & Actinidia chinensis \\
\hline & DN41612_c1_g1- & $\mathrm{Cd}$ & 2680 & Protein DMP2-like & Olea europaea \\
\hline & DN21404_C0_g1+ & $\mathrm{Cu}$ & 1731 & Predicted protein & Hordeum vulgare \\
\hline & DN22677_c0_g1+ & $\mathrm{Cu}$ & 1296 & Heavy-metal-associated isoprenylated plant protein, partial & Actinidia chinensis \\
\hline & DN21179_c0_g1+ & $\mathrm{Mn}$ & 337 & Ent-copalyl diphosphate synthase & Actinidia chinensis \\
\hline
\end{tabular}

+ is positive correlation,-is negative correlation, the same below

taxonomic level, but they have not been included in Fig. 6 due to the low richness level.
Soil microbial diversity in the root zone

The alpha diversity indices at $97 \%$ similarity for $\mathrm{M}-\mathrm{Cd}$ and M-CK are shown in Table 6. The Chao1 and ACE 
Table 5 Sequencing results for rhizosphere fungi

\begin{tabular}{llllllllll}
\hline Sample & Input & Filtered & $\begin{array}{l}\text { Percentage of input } \\
\text { that passed filter }\end{array}$ & Denoised & Merged & $\begin{array}{l}\text { Percentage of } \\
\text { input merged }\end{array}$ & Non-chimeric & $\begin{array}{l}\text { Percentage of } \\
\text { input non- } \\
\text { chimeric }\end{array}$ & $\begin{array}{l}\text { Length } \\
\text { (245- } \\
\text { 259 bp) }\end{array}$ \\
\hline M-Cd & 76,848 & 65,999 & $86.05 \%$ & 65,699 & 64,984 & $84.71 \%$ & 64,661 & $84.28 \%$ & $93.66 \%$ \\
M-CK & 78,259 & 70,496 & $90.18 \%$ & 70,198 & 69,345 & $88.71 \%$ & 67,148 & $86.03 \%$ & $94.82 \%$ \\
\hline
\end{tabular}

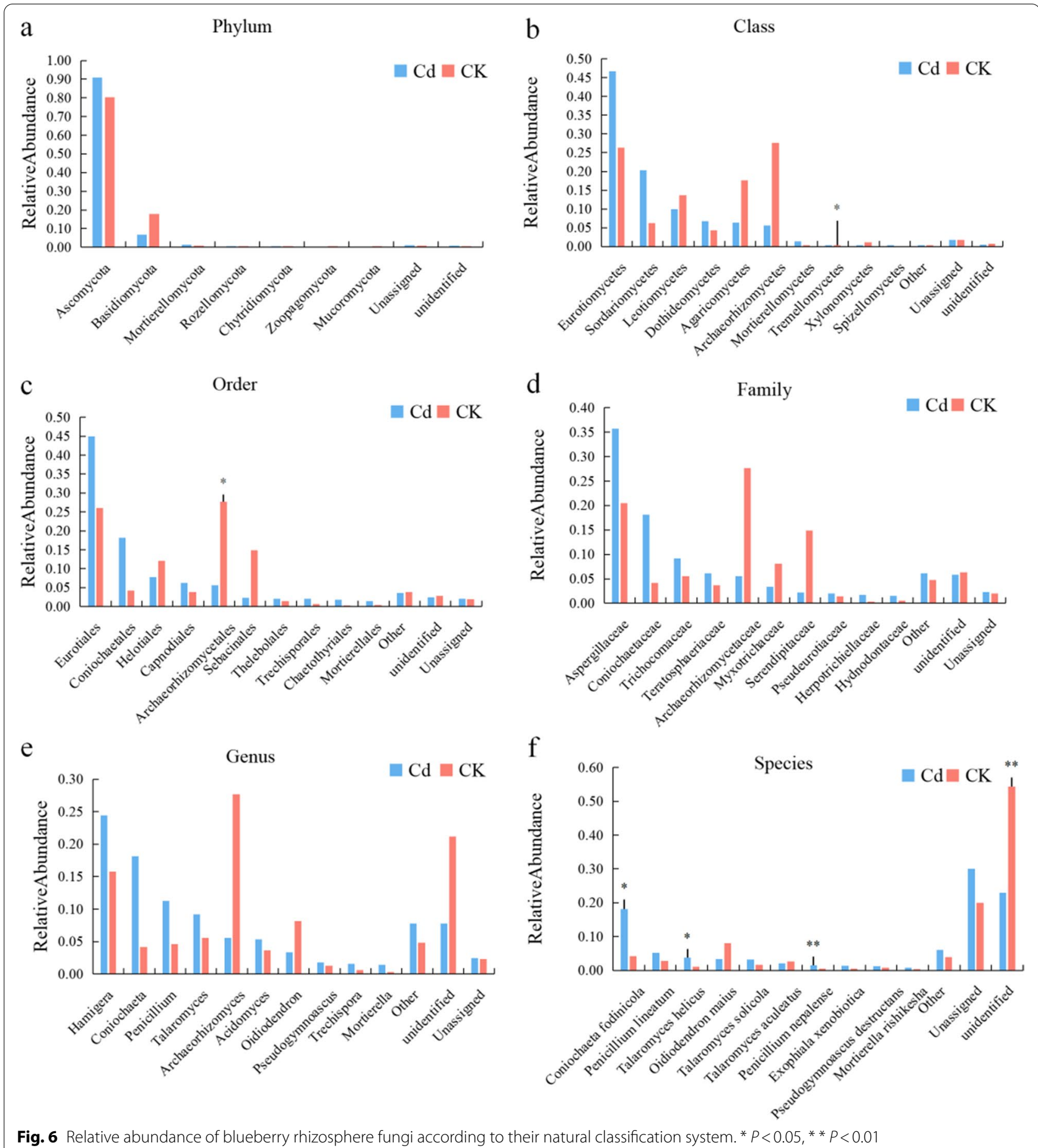


indices are used to measure species abundance (i.e. the number of species), and the Shannon and Simpson indices are used to measure species diversity [41]. It can be seen that the differences in the Chao1, ACE, Shannon and Simpson indices between $\mathrm{M}-\mathrm{Cd}$ and $\mathrm{M}-\mathrm{CK}$ are not significant, which indicates that there are no clear differences in soil microbial diversity between $\mathrm{M}-\mathrm{Cd}$ and $\mathrm{M}-\mathrm{CK}$.

\section{Correlation analysis between rhizosphere soil microbial richness and soil Cd levels}

The results of the correlation analysis between soil $\mathrm{Cd}$ content and species richness are presented in Table 7; values of $R \geq 0.8$ and $P \leq 0.05$ were selected as the screening conditions. Two classes (Tremellomycetes and Chytridiomycetes), six orders (e.g. Filobasidiales), seven families (e.g. Conioscyphaceae), 12 genera (e.g. Trichocladium) and 6 species (e.g. Trichocladium opacum) were positively correlated with soil Cd level.

\section{Discussion}

\section{Overall transcription of blueberry under Cd stress}

Some studies have suggested that blueberry, a plant that grows in acid soil, is the dominant species in acid soil that is contaminated with heavy metals, but there has been little research on the mechanism of heavy metal tolerance in this species at the molecular level. The present study has utilized high-throughput sequencing technology, which can provide information about the response of plants to heavy metal stress. A total of 84374 annotated genes, which included 3370 DEGs, were obtained from the root, stem, leaf and fruit tissue of blueberry plants that had been subjected to Cd stress. The DEGs were mainly involved in plant hormone signal transduction, $\mathrm{ABC}$ transport, the MAPK signal transduction pathway, starch and sucrose metabolism, riboflavin metabolism, porphyrin and chlorophyll metabolism, mismatch repair, photosynthesis, flavonoid biosynthesis and sphingolipid metabolism. The metabolic pathways of DEG enrichment also differed according to the specific tissue in which they were evaluated. For example, the DEGs in root tissue were mainly involved in glycosaminoglycan degradation, glycosphingolipid biosynthesis, sphingolipid metabolism, amino sugar and nucleotide sugar metabolism, and other degradation pathways related to cell wall synthesis and breakdown. The DEGs in stem tissue were associated with various defense responses (such as responses to water deficit, hydrogen peroxide and salt stress) and in signal transduction (such as the MAPK signal transduction pathway, plant hormone signal transduction and $\mathrm{ABC}$ transport). The DEGs in leaf tissue were mainly involved in photosynthesis, diterpenoid biosynthesis, circadian rhythms, oxidative

Table 6 Alpha diversity indices at 97\% similarity for soil microbial diversity

\begin{tabular}{lcccccc}
\hline Samples & Observed & Chao1 & ACE & Shannon & Simpson & Coverage \\
\hline M-Cd & 171.33 & 171.33 & 171.41 & 3.13 & 0.12 & 1.00 \\
M-CK & 150.67 & 150.73 & 151.01 & 2.87 & 0.14 & 1.00 \\
P-value & 0.38 & 0.40 & 0.40 & 0.40 & 1.00 & 0.35 \\
\hline
\end{tabular}

Table 7 Correlation between rhizosphere soil microbial classification and soil Cd levels

\begin{tabular}{|c|c|c|c|c|}
\hline Class & Order & Family & Genus & Species \\
\hline $\begin{array}{l}\text { Tremellomycetes + } \\
\text { Chytridiomycetes + }\end{array}$ & $\begin{array}{l}\text { Filobasidiales }+ \\
\text { Conioscyphales }+ \\
\text { Chytridiales }+ \\
\text { Eurotiales }+ \\
\text { Archaeorhizomycetales- } \\
\text { Chaetothyriales }+\end{array}$ & $\begin{array}{l}\text { Conioscyphaceae }+ \\
\text { Chytridiaceae }+ \\
\text { Rutstroemiaceae }+ \\
\text { Vibrisseaceae }+ \\
\text { Cephalothecaceae }+ \\
\text { Filobasidiaceae }+ \\
\text { Archaeorhizomycetaceae- }\end{array}$ & $\begin{array}{l}\text { Trichocladium- } \\
\text { Conioscypha+ } \\
\text { Lambertella+ } \\
\text { Cephalotheca+ } \\
\text { Naganishia + } \\
\text { Chaetomium + } \\
\text { Setophaeosphaeria- } \\
\text { Mrakia + } \\
\text { Ilyonectria + } \\
\text { Paecilomyces + } \\
\text { Archaeorhizomyces- } \\
\text { Talaromyces + }\end{array}$ & $\begin{array}{l}\text { Trichocladium opacum- } \\
\text { Coniochaeta fodinicola+ } \\
\text { Lambertella tubulosa+ } \\
\text { Spirosphaera caricigraminis + } \\
\text { Cephalotheca sulfurea+ } \\
\text { Talaromyces helicus+ } \\
\text { Unidentified- }\end{array}$ \\
\hline
\end{tabular}


phosphorylation, RNA polymerase activity, plant hormone signal transduction and flavonoid biosynthesis. The DEGs in fruit tissue were mainly associated with diterpenoid biosynthesis, oxidative phosphorylation, galactose metabolism, starch and sucrose metabolism, phenylpropanoid biosynthesis and carotenoid biosynthesis. A study of cadmium stress in cotton (Gossypium hirsutum) found that most DEGs were associated with catalytic activity and metal ion binding. Cotton responded to cadmium stress by increasing cell wall thickness, antioxidant activity and detoxification. It has been reported that the genes involved in preventing transport of $\mathrm{Cd}$ to rice grains include OsIRT1, OsNramp5, OsVIT2, OsNRT1.5a and OsABCC1 [42]. Transcriptome analysis of the leaves and roots of Broussonetia papyrifera showed that $\mathrm{Cd}$ stress affected 47 KEGG pathways, mainly involving $b H L H, M Y B$ and other important transcription factors, plant-pathogen interactions, phenylpropanoid biosynthesis, plant hormone signal transduction, and other protein synthesis and metabolism processes [43]. In response to $\mathrm{Cd}$ stress, the main metabolic response of willow twig (Panicum virgatum) involves activation of redoxrelated metabolism, and 21 different shock transcription factors (HSFs) and 22 heat shock proteins (HSPs) are differentially expressed [44].These results are similar to the findings of the present study.

Most of the previous studies on the interaction between plants and heavy metals were conducted on the roots and leaves of herbaceous plants, and confirmed that the root system was the first organ to exhibit the effects of heavy metal toxicity, due to its direct exposure to heavy metals in the soil [22]. Interestingly, however, the results of the present study showed that in blueberry the DEGs were mainly concentrated in the stem, and the number of DEGs was lowest in root tissue (even lower than the number in leaf and fruit tissue). There were 13.7-fold more DEGs in stem tissue than in root tissue. The DEGs were involved in different metabolic pathways in each of these tissues, which indicated that there were also differences in the physiological responses of each type of tissue to Cd stress.

\section{Accumulation of and competition between heavy metals}

Almost all plants accumulate essential heavy metals such as $\mathrm{Fe}, \mathrm{Mn}, \mathrm{Cu}$ and $\mathrm{Zn}$ in the body, and these heavy metals are also very important for the growth and development of plants. The absorption and accumulation of heavy metals by plants are dependent not only on the physical and chemical properties of the external environment, but also on the characteristics of the plant [45]. It has been shown that the levels of seven heavy metals in wheat grains are higher than those in maize grains. Moreover, as the heavy metal content of the soil increases, the biological concentration coefficient (BFC) of heavy metals in wheat and maize grains decreases exponentially [46]. When eggplant (Solanum melongena) was planted in polluted sludge, the heavy metal content of the roots was reported to be much higher than that of the buds and fruits, and the plant could more readily absorb $\mathrm{Cd}$ than either $\mathrm{Pb}$ or $\mathrm{Ni}$ from the soil [47]. These studies show that the type and content of heavy metals in different tissues vary due to differences in the transfer and fixation of heavy metals by plants.

In the study of heavy metal stress on blueberry, most of them are around the leaves and fruits $[15,48]$. In a previous study, seedlings of the blueberry variety 'Bluecrop' accumulated $\mathrm{Cd}$ in the roots, but the $\mathrm{Cd}$ content of the stems was also very high, and the difference in Cd levels between the two tissues was not statistically significant [21]. In the present study, Cd was mainly accumulated in the stem, which was consistent with the finding of the highest number of DEGs in stem tissue, and also demonstrated the reliability of the sequencing results. The discrepancy in the results of the two studies may be due to the fact that the late-ripening blueberry variety 'Bluegold' was used in the present study, in order to prolong the stress treatment period, and different blueberry varieties accumulate $\mathrm{Cd}$ in different tissues. It can be confirmed that blueberry mainly accumulates $\mathrm{Cd}$ in the roots and stems, and the lowest level of accumulation is in the fruits, where the $\mathrm{Cd}$ concentration is much lower than that in the soil, roots, stems and leaves. The same research also showed that in Vitis vinifera the $\mathrm{Cd}$ content of the fruits of plants grown in polluted soil was lower than that of any other tissues [49]. However, the differences in heavy metal accumulation among different blueberry varieties need to be clarified in future research studies.

It has been widely reported that $\mathrm{Cd}^{2+}$ interacts with other metal cations in plants and soils [50]. In the present study we found that the $\mathrm{Mn}, \mathrm{Fe}, \mathrm{Cu}$ and $\mathrm{Zn}$ content of blueberry tissues was affected by $\mathrm{Cd}$, and the diffusion of metal cations in soil was also affected by $\mathrm{Cd}^{2+}$. Mn was mainly absorbed by plants via active transport through the roots, and had an antagonistic effect on Cd accumulation [51]. External application of Mn could alleviate the toxicity of $\mathrm{Cd}$ to some extent [52], but the Mn content of blueberry roots was not affected by $\mathrm{Cd}$, although the latter significantly reduced the transfer of $\mathrm{Mn}$ to stems, leaves and fruits. The passive diffusion of DGT showed that the Mn content increased with increasing $\mathrm{Cd}$ content, which indicated that although $\mathrm{Cd}$ had no effect on the $\mathrm{Mn}$ content of blueberry roots, the process of active absorption of $\mathrm{Mn}$ by roots may be affected. 
Fe is an important element in chlorophyll synthesis, and an increase in Cd levels in leaves will lead to iron deficiency and chlorosis. An increase in Fe will inhibit the absorption of $\mathrm{Cd}$ [53], and sulfate $\left(\mathrm{SO}_{4}{ }^{2-}\right)$ can promote the absorption of Fe by increasing competition [54]. However, in the present study, the increase in soil $\mathrm{Cd}$ concentration dramatically reduced the Fe content of blueberry roots, and to a lesser extent reduced that of leaves and fruits, but did not affect the Fe content of stems. The decrease in Fe content was due to the fact that Cd not only occupied the cation transport channel [55], but also inhibited the passive diffusion of Fe from the soil to the root tissue.

$\mathrm{Cu}$ has a role in the multi-channel oxidation process in plants, but there have been few studies on the interaction between $\mathrm{Cu}$ and $\mathrm{Cd}$. It has been reported that the addition of excessive amounts of $\mathrm{Cd}$ to the culture medium can reduce the $\mathrm{Cu}$ and $\mathrm{Ca}$ content of the xylem in Picea abies [56]. Similar results have been obtained in studies of some grains and beans [57]. In the present study, too, severe $\mathrm{Cd}$ stress significantly reduced the $\mathrm{Cu}$ content of blueberry roots, stems and leaves, and even significantly decreased the passive absorption of $\mathrm{Cu}$ in soil.

$\mathrm{Zn}^{2+}$ in soil has been proved to be a competing ion for $\mathrm{Cd}^{2+}$ [58]. Zn has been reported to inhibit Cd accumulation in all organs of tomato (Lycopersicon esculentum) [59], but to significantly enhance $\mathrm{Cd}$ accumulation in petioles and reduce accumulation in the roots of Potentilla griffithii [60]. The Zn content of blueberry was strongly affected by plant exposure to $\mathrm{Cd}$. Specifically, the $\mathrm{Zn}$ content of roots and leaves was significantly inhibited, but $\mathrm{Zn}$ accumulation in stems was significantly promoted, and the passive absorption of $\mathrm{Zn}$ in soil was also increased as Mn.

It is clear that treatment with Cd affected the $\mathrm{Mn}, \mathrm{Fe}$, $\mathrm{Cu}$ and $\mathrm{Zn}$ content of blueberry tissues, which is consistent with the findings of previous studies [24]. In blueberry under $\mathrm{Cd}$ stress, the $\mathrm{Cd}$ content of all tissues increased, although the magnitude of the increase varied widely. The $\mathrm{Cd}$ content was highest in stem tissue, followed by root and stem tissues (which had an almost identical Cd content), and was lowest in fruit tissue. As the Cd content of soil can be as high as $400 \mathrm{mg} / \mathrm{kg}$, but the amount of $\mathrm{Cd}$ transferred from blueberry to fruit is very small $(1 \mathrm{mg} / \mathrm{kg})$, it is difficult to reach such a high level of $\mathrm{Cd}$ pollution in the soil in the external pollution area, so under the general pollution level, the content of $\mathrm{Cd}$ in fruit may be lower.

\section{Effects of heavy metals on rhizosphere microorganisms}

Soil microorganisms are an important component of the soil ecosystem, especially for plants such as blueberry, which has roots with a low absorption capacity and uses fungal mycorrhiza to improve nutrient uptake and support growth. The interaction between soil microorganisms and soil environmental factors is extremely complex. In heavy-metal-contaminated soil, some microorganisms can modify, degrade or precipitate heavy metal compounds, while soil environmental factors can screen microbial communities [61]. In the present study, although the application of $\mathrm{Cd}$ did not have a significant impact on the biodiversity of soil fungi, it did significantly affect the dominant species of soil fungi. In fact, $\mathrm{Cd}$ is the preferred method of screening for soil fungi. At the phylum level, the two samples were mainly concentrated in the Ascomycota and Basidiomycota, while at the class level, growth of Agaricomycetes and Archaeorhizomycetes was inhibited by $\mathrm{Cd}$, but growth of Eurotiomycetes and Sordariomycetes was promoted. At the order and family level, growth of both the Archaeorhizomycetales (of the Archaeorhizomycetes) and the Sebacinales (of the Agaricomycetes) was inhibited by $\mathrm{Cd}$. The latter two orders and families have been demonstrated to be the dominant species in the mycorrhizal fungal community associated with blueberry [61], and fungi belonging to the order Sebacinales have the ability to replace ericoid mycorrhizae (ERM) associated with blueberry $[29,62]$. In contrast, Cd stress promoted growth of fungi belonging to the Aspergillaceae and Trichocomaceae (of the Eurotiales) and the Coniochaetaceae (of the Coniochaetales). Some fungi belonging to these three families are highly tolerant of extreme environmental conditions, such as high temperature, high salt levels and high concentrations of heavy metals. For example, it has been reported that the dominant fungi in contaminated soil collected from an open pit mining area in Iglesiente (Sardinia, Italy) belong to the Trichocomaceae [63], while members of the Coniochaetaceae are heterotrophic ascomycetes that are widely distributed in terrestrial ecosystem, but are most numerous in extreme habitats [64]. Many species of the Coniochaetaceae are root endophytic fungi [65], but further studies are needed to determine whether they can be inoculated into blueberry roots to form endophytic fungi. At the taxonomic level of genus and species, some species with a high degree of adaptability to extreme environments have been preserved, such as Coniochaeta fodinicola and Talaromyces helicus, which are considered to be the dominant fungi in acid, industrial- and mining-contaminated soils, and are used to remove soil pollutants [66-68].

\section{Mechanism of $\mathrm{Cd}$ regulation in blueberry}

After Cd entered the blueberry planting soil, it reflected the changes of the external environment of the root 
system. These changes altered the composition of the soil fungal community. The growth of several of the main mycorrhizal fungi of blueberry was inhibited, and some fungi that are resistant to extreme environmental conditions exhibited vigorous growth. At the same time, $\mathrm{Cd}$ altered the status of heavy metal absorption by the root system, which stimulated a series of reactions within the blueberry plant (Fig. 7).

First, Cd was absorbed along with other metal cations by the roots. When it had penetrated the root tissue by strong passive diffusion, reactions were induced in the root cell wall and cell membrane, such as sphingolipid metabolism (map00600), amino sugar and nucleoside sugar metabolism (map00520), other glycan degradation (map00511), and galactose metabolism (map00052). It was found that bgal3, os03g0165400, at5g34940, at3g59480, chitinase, bxl2, xyl2 and chil3 were up-regulated, but only JKD was down-regulated. All of these results indicated that the cell wall and cell membrane of blueberry root are important sites for $\mathrm{Cd}$ signal sensing, which is consistent with previous findings in studies on wheat(Triticum aestivum) [69]. The upward transport of $\mathrm{Cd}$ in blueberry resulted in its gradual accumulation in root and stem tissue. The stem tissue showed the strongest response to $\mathrm{Cd}$, most markedly with the expression of PR-1, Xa21, PYl4 and MPK16 in the MAPK signaling pathway (map04016) and $A B F 2$, PYl4, IAA, EBF2, XTH23 and SAPK1 in the hormone signaling pathway (map04075). At all levels of phosphorylation in the MAPK pathway the changes in MAPKK and MAPKKK led to the up-regulation of WRKY33 expression, which promotes an increase in PAD3, as has also been reported in Arabidopsis thaliana [70]. In addition, the response of blueberry to $\mathrm{Cd}$ stress is similar to its response to salt stress and drought stress. In the hormone signal transduction pathway, the up-regulated expression of abscisic acid receptor (PYL) leads to the up-regulated expression of serine/threonine protein kinase in response to $\mathrm{Cd}$ stress. The plant response to $\mathrm{Cd}$ stress also led to upregulation of DEGs in the plant-pathogen interaction pathway (map04626). Cyclic nucleotide-gated channels (CNGCs) have an important role in control of the plant-pathogen interaction pathway [71]. The up-regulation of cngc1/3 in blueberry results in the expression of calcium-dependent protein kinase (CDPK), which affects the up-regulation of calmodulin (CaM/ CML), RPM1, RPS2, HSP90 and a series of diseaseresistance-related genes. These genes jointly cause blueberry allergy. In addition, differential gene expression associated with phenylpropanoid biosynthesis (map00940), flavonoid biosynthesis (map00941), ascorbate and alginate metabolism (map00053) and carotenoid biosynthesis (map00906) also played a role in the $\mathrm{Cd}$ defense response of blueberry.

Several genes for ABC transporters (map02010) were up-regulated in blueberry stem, such as $A B C C 3$ and $A B C G 5$ [72]. ABCG-type ABC transporters were confirmed to be involved in plant hormone transport. When

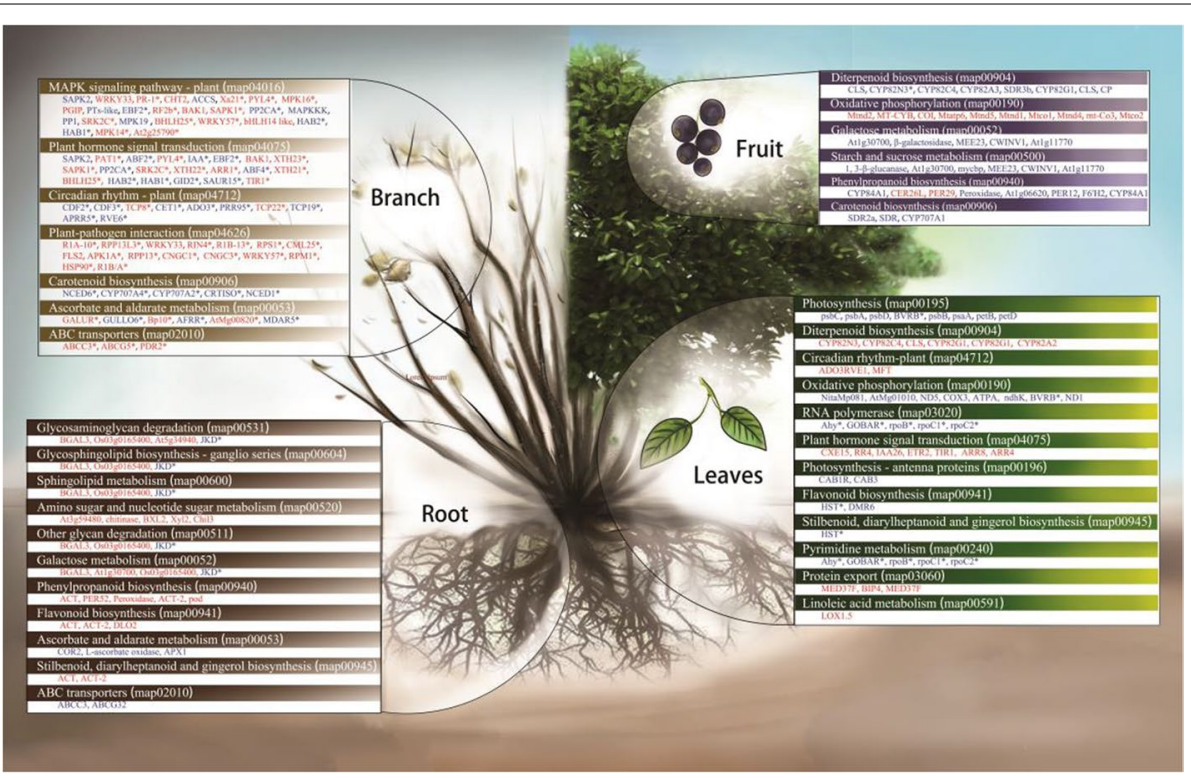

Fig. 7 Differentially Expressed Genes in Differential Metabolic Pathways in Various Tissues of Blueberry. The red font is the up-regulated expression gene, and the blue font is the down-regulated expression gene. *It means that the difference is above the extremely significant level 
Cd was transported to blueberry leaves, the main effect was on the photosynthesis pathway (map00195), in which all DEGs were down-regulated (such as PSBC, PSBA, $P S B D$ and $B V R B$ ), while all DEGs in the cytochrome P450 (CYPs) pathway of diterpenoid biosynthesis (map00904) were up-regulated. This indicated that the transfer of $\mathrm{Cd}$ to blueberry leaves had a marked effect on the photoperiod of the leaves, and the CYPS of blueberry leaves were involved in the regulation and detoxification of $\mathrm{Cd}$. In the present study, the fruit was shown to be the tissue with the lowest $\mathrm{Cd}$ content. In the pathway of oxidative phosphorylation (map00190), Mtnd2, MT$C Y \mathrm{~B}, \mathrm{COI}$ and Mtatp6 were up-regulated, while diterpenoid biosynthesis (map00904), oxidative phosphorylation (map00190), galactose metabolism (map00052), and starch and sucrose metabolism (map00500) were up-regulated. In the pathways of phenylpropanoid biosynthesis (map00940) and carotenoid biosynthesis (map00906), most of the DEGs were down-regulated. However, further research is needed to confirm the mechanism whereby fruit tissue inhibits the entry of $\mathrm{Cd}$.

\section{Conclusions and future prospects}

Blueberry, a perennial shrub that thrives in acid soil, is considered to be the dominant plant species in acid soils polluted with heavy metal compounds. However, the mechanisms of heavy metal absorption and metabolism in blueberry are unclear. Although high-throughput sequencing technology has enabled increasing numbers of studies on the mechanisms of plant regulation and metabolism of heavy metals, blueberry exhibits some unusual features. In response to Cd stress, the signal transduction, defense and detoxification mechanisms of this plant differ in each tissue type, reflecting the synergy and characteristics of each organization. In the present study, a total of 84374 annotated genes were obtained from four tissue samples of blueberry by high-throughput sequencing technology, including 3370 DEGs, of which there were 184 DEGs in root tissue, 2521 DEGs in stem tissue, 360 DEGs in leaf tissue and 305 DEGs in fruit tissue. These DEGs were enriched in different metabolic pathways in different tissues. The $\mathrm{Fe}, \mathrm{Mn}, \mathrm{Cu}, \mathrm{Zn}$ and $\mathrm{Cd}$ content of different tissues, soil and DGT of blueberry was determined by ICP-MS. It was found that the main Cd accumulation site was the stem, which was consistent with the sequencing results. The $\mathrm{Cd}$ content of stem tissue was higher than that of the other tissues, whereas the lowest $\mathrm{Cd}$ content was found in fruit tissue. Cd competed with other metal cations, and this severely affected the metabolism of other metal elements in blueberry tissues. Only through active absorption into blueberry roots, but also through a large number of passive diffusion into the roots. $\mathrm{Cd}$ in the soil also had a significant effect on the mycorrhizal fungi associated with blueberry. Growth of the dominant populations of mycorrhizal fungi, namely members of the Archaeorhizomycetes and Sebacinales, was inhibited, and members of the Coniochaetaceae, which can tolerate extreme environments, gradually became the dominant population. Thus, in the presence of the acid soil conditions that are necessary for growth of blueberry, Cd alters the growth environment of this plant and has toxic effects on its tissues. However, blueberry can resist the toxicity of $\mathrm{Cd}$ through its own metabolic regulatory mechanism.

The results of the present study, which demonstrate excessive accumulation of $\mathrm{Cd}$ and abundant DEGs in blueberry stem under $\mathrm{Cd}$ stress, point to interesting new avenues for future research. However, the most pressing need is for studies to improve our understanding of the long-distance transport of heavy metals in blueberry, the inhibition of $\mathrm{Cd}$ transport into fruit, the effect of $\mathrm{Cd}$ on the composition of the community of attached fungi and endophytic fungi in blueberry roots, and the regulation of $\mathrm{Cd}$ by bacteria in blueberry roots.

\section{Abbreviations}

Cd: Cadmium; Zrt/IRT: Zinc iron regulatory protein; GSH: Glutathione; DEGs: Differentially expressed genes; qRT PCR: Quantitative real-time PCR; GAPDH: Glyceraldehyde-3-phosphate dehydrogenase; ICP-MS: Inductively coupled plasma mass spectrometry; DGT: Diffusive gradients in thin films; OTU:

Operational taxonomic unit; GO: Gene ontology; KEGG: Kyoto Encyclopedia of Genes and Genomes; MAPK: Mitogen-activated protein kinase; HSFs: Shock transcription factors; HSPs: Heat shock proteins; BFC: Biological concentration coefficient; PYL: Abscisic acid receptor; CNGCs: Cyclic nucleotide-gated channels; CDPK: Calcium-dependent protein kinase; CaM/CML: Calmodulin; CYPS: Cytochrome P450; GEO: Gene Expression Omnibus.

\section{Acknowledgements}

We thank HaoYu Shen (Hangzhou Lianchuan Bio Technologies Co) for providing help in the experiments.

\section{Authors' contributions}

SPC participated in the trial design and manuscript writing; QQZ participated in the data analysis and revised the manuscript; XLC participated in the management of the trial process; ZXJ revised the manuscript; TD and YM participated in the trial process management, and all authors approved.

\section{Funding}

This work was supported by the project of Jilin Science and Technology Innovation and Development Plan (20190104153) and the doctoral start-up fund of ilin Agricultural Science and Technology University (Jinongyuanhezi [School 20190540]). Jilin Science and Technology Innovation and Development Plan supports the blueberry cultivation management and soil microbial diversity measurement in this research, and the doctoral start-up fund of Jilin Agricultural Science and Technology University initiates funds to support the blueberry transcriptomics measurement and the purchase of biochemical reagents in this research.

\section{Availability of data and materials}

The sequencing data has been submitted to NCBI Gene Expression Omnibus(GEO) database (https://www.ncbi.nlm.nih.gov/geo/) under the accession number of GSE168446 (https://www.ncbi.nlm.nih.gov/geo/query/ acc.cgi?acc $=$ GSE168446). 


\section{Declarations}

Ethics approval and consent to participate

Not applicable.

\section{Consent for publication}

Not applicable.

\section{Competing interests}

The authors declare that they have no competing interests.

\section{Author details}

${ }^{1}$ College of Agriculture, Jilin Agricultural Science and Technology University, Jilin 132101, PR China. ${ }^{2}$ Design Office, Jilin Greening Management Center, Jilin 132011, PR China.

Received: 19 March 2021 Accepted: 9 July 2021

Published online: 20 August 2021

\section{References}

1. Zhang H, Reynolds M. Cadmium exposure in living organisms: a short review. Sci Total Environ. 2019;678:761-7.

2. Kubier A, Wilkin RT, Pichler T. Cadmium in soils and groundwater: a review. Appl Geochem. 2019;108:104388.

3. Wang P, Chen H, Kopittke PM, Zhao F-J. Cadmium contamination in agricultural soils of China and the impact on food safety. Environ Pollut. 2019;249:1038-48.

4. Kirkham MB. Cadmium in plants on polluted soils: effects of soil factors, hyperaccumulation, and amendments. Geoderma. 2006;137(1-2):19-32.

5. Hayat MT, Nauman M, Nazir N, Ali S, Bangash N. Environmental hazards of cadmium: past, present, and future. Cadmium Toxicity Tolerance Plants. 2019;163-83. https://doi.org/10.1016/B978-0-12-814864-8.00007-3.

6. Mitra A, Chatterjee S, Gupta DK. Phytoremediation of heavy metals: an overview and new insight on green approaches. In: Plant ecophysiology and adaptation under climate change: mechanisms and perspectives II. 2020. p. 701-24.

7. Van der Ent A, Baker AJM, Reeves RD, Pollard AJ, Schat H. Hyperaccumulators of metal and metalloid trace elements: facts and fiction. Plant Soil. 2013;362(1):319-34

8. Silver B, Allen M. Blueberries. J Agric Food Inf. 2012;13(1):7-13.

9. Silva S, Costa EM, Veiga M, Morais RM, Calhau C, Pintado M. Health promoting properties of blueberries: a review. Crit Rev Food Sci Nutr. 2020;60(2):181-200.

10. Kalt W, Cassidy A, Howard LR, Krikorian R, Stull AJ, Tremblay F, et al. Recent research on the health benefits of blueberries and their anthocyanins. Adv Nutr. 2020;11(2):224-36.

11. Mroz L, Demczuk M. Contents of phenolics and chemical elements in bilberry (Vaccinium myrtillus L.) leaves from copper smelter area (SW Poland). Pol J Ecol. 2010;58(3):475-86.

12. Uhlig $C$, Junttila $O$. Airborne heavy metal pollution and its effects on foliar elemental composition of Empetrum hermaphroditum and Vaccinium myrtillus in Sør-Varanger, northern Norway. Environ Pollut. 2001;114(3):461-9.

13. Gjengedal $E$, Steinnes $E$. The mobility of metals in the soil-plant system in manipulated catchments: plant species suitable for biomonitoring of $\mathrm{Cd}$, $\mathrm{Pb}, \mathrm{Zn}$, and Rb. Ecol Eng. 1994;3(3):267-78.

14. Salemaa M, Derome J, Helmisaari H-S, Nieminen T, Vanha-Majamaa I. Element accumulation in boreal bryophytes, lichens and vascular plants exposed to heavy metal and sulfur deposition in Finland. Sci Total Environ. 2004;324(1-3):141-60.

15. Kandziora-Ciupa M, Ciepał R, Nadgórska-Socha A, Barczyk G. A comparative study of heavy metal accumulation and antioxidant responses in Vaccinium myrtillus L. leaves in polluted and non-polluted areas. Environ Sci Pollut Res. 2013;20(7):4920-32

16. Shorthouse JD, Bagatto G. Potential role of lowbush blueberry (Vaccinium angustifolium) in colonizing metal-contaminated ecosystems. In: Restoration and recovery of an industrial region. 1995. p. 247-55.
17. Chen S, Liu Y, Deng Y, Liu Y, Dong M, Tian Y, et al. Cloning and functional analysis of the VCCXIP4 and VCYSL6 genes as Cd-regulating genes in blueberry. Gene. 2019;686:104-17.

18. Chibuike GU, Obiora SC. Heavy metal polluted soils: effect on plants and bioremediation methods. Appl Environ Soil Sci. 2014;14:1-12. https://doi. org/10.1155/2014/752708.

19. Dubey S, Shri M, Gupta A, Rani V, Chakrabarty D. Toxicity and detoxification of heavy metals during plant growth and metabolism. Environ Chem Lett. 2018;16(4):1169-92.

20. Shanmugaraj BM, Malla A, Ramalingam S. Cadmium stress and toxicity in plants: an overview. In: Cadmium toxicity and tolerance in plants. 2019. p. 1-17. https://doi.org/10.1016/B978-0-12-814864-8.00001-2.

21. Chen S, Li Y, Ma X, Guo L, He Y, Ren Z, et al. Analysis of potential strategies for cadmium stress tolerance revealed by transcriptome analysis of upland cotton. Sci Rep. 2019;9(1):1-13.

22. Zhu H, Ai H, Cao L, Sui R, Ye H, Du D, et al. Transcriptome analysis providing novel insights for $\mathrm{Cd}$-resistant tall fescue responses to $\mathrm{Cd}$ stress. Ecotoxicol Environ Saf. 2018;160:349-56.

23. Zhou Q, Guo J-J, He C-T, Shen C, Huang Y-Y, Chen J-X, et al. Comparative transcriptome analysis between low-and high-cadmium-accumulating genotypes of pakchoi (Brassica chinensis L.) in response to cadmium stress. Environ Sci Technol. 2016;50(12):6485-94.

24. Chen S, Wang Q, Lu H, Li J, Yang D, Liu J, et al. Phenolic metabolism and related heavy metal tolerance mechanism in Kandelia Obovata under Cd and Zn stress. Ecotoxicol Environ Saf. 2019;169:134-43.

25. Giller KE, Witter E, McGrath SP. Heavy metals and soil microbes. Soil Biol Biochem. 2009:41(10):2031-7.

26. Kuźniar A, Banach A, Stępniewska Z, Frąc M, Oszust K, Gryta A, et al. Community-level physiological profiles of microorganisms inhabiting soil contaminated with heavy metals. Int Agrophys. 2018;32(1):101-9.

27. Pajuelo E, Rodríguez-Llorente ID, Lafuente A, Caviedes MÁ. Legumerhizobium symbioses as a tool for bioremediation of heavy metal polluted soils. Soil Sediment Contam. 2011;95-123.

28. Lin $Y, Y e Y, H u Y$, Shi $H$. The variation in microbial community structure under different heavy metal contamination levels in paddy soils. Ecotoxicol Environ Saf. 2019:180:557-64.

29. Morvan S, Meglouli H, Lounès-Hadj Sahraoui A, Hijri M. Into the wild blueberry (Vaccinium angustifolium) rhizosphere microbiota. Environ Microbiol. 2020;22(9):3803-22.

30. Gui LX, Lu SS, Chen Q, Yang L, Xiao JX. iTRAQ-based proteomic analysis reveals positive impacts of arbuscular mycorrhizal fungi inoculation on photosynthesis and drought tolerance in blueberry. Trees. 2020;35:1-12. https://doi.org/10.1007/s00468-020-02015-5.

31. Liu XM, Xu QL, Li QQ, Zhang H, Xiao JX. Physiological responses of the two blueberry cultivars to inoculation with an arbuscular mycorrhizal fungus under low-temperature stress. J Plant Nutr. 2017;40(18):2562-70

32. Manquián-Cerda K, Cruces E, Escudey M, Zúñiga G, Calderón R. Interactive effects of aluminum and cadmium on phenolic compounds, antioxidant enzyme activity and oxidative stress in blueberry (Vaccinium corymbosum L.) plantlets cultivated in vitro. Ecotoxicol Environ Saf. 2018:150:320-6.

33. Mortazavi A, Williams BA, McCue K, Schaeffer L, Wold B. Mapping and quantifying mammalian transcriptomes by RNA-Seq. Nat Methods. 2008;5(7):621-8.

34. Patro R, Duggal G, Love MI, Irizarry RA, Kingsford C. Salmon provides fast and bias-aware quantification of transcript expression. Nat Methods. 2017:14(4):417-9.

35. Robinson MD, McCarthy DJ, Smyth GK. edgeR: a bioconductor package for differential expression analysis of digital gene expression data. Bioinformatics. 2010;26(1):139-40.

36. Wang Y, Ding S, Gong M, Xu S, Xu W, Zhang C. Diffusion characteristics of agarose hydrogel used in diffusive gradients in thin films for measurements of cations and anions. Anal Chim Acta. 2016;945:47-56.

37. Xu D, Wu W, Ding S, Sun Q, Zhang C. A high-resolution dialysis technique for rapid determination of dissolved reactive phosphate and ferrous iron in pore water of sediments. Sci Total Environ. 2012:421:245-52.

38. Caporaso JG, Kuczynski J, Stombaugh J, Bittinger K, Bushman FD, Costello EK, et al. QIIME allows analysis of high-throughput community sequencing data. Nat Methods. 2010;7(5):335-6.

39. Edgar RC. Search and clustering orders of magnitude faster than BLAST. Bioinformatics. 2010;26(19):2460-1. 
40. Zhu D, Tanabe S-H, Yang C, Zhang W, Sun J. Bacterial community composition of South China Sea sediments through pyrosequencing-based analysis of 16S rRNA genes. PLoS One. 2013;8(10):e78501.

41. Grice EA, Kong HH, Conlan S, Deming CB, Davis J, Young AC, et al. Topographical and temporal diversity of the human skin microbiome. Science. 2009;324(5931):1190-2.

42. Liu A, Zhou Z, Yi Y, Chen G. Transcriptome analysis reveals the roles of stem nodes in cadmium transport to rice grain. BMC Genomics. 2020;21(1):1-16.

43. Xu Z, Dong M, Peng X, Ku W, Zhao Y, Yang G. New insight into the molecular basis of cadmium stress responses of wild paper mulberry plant by transcriptome analysis. Ecotoxicol Environ Saf. 2019;171:301-12.

44. Song G, Yuan S, Wen X, Xie Z, Lou L, Hu B, et al. Transcriptome analysis of Cd-treated switchgrass root revealed novel transcripts and the importance of HSF/HSP network in switchgrass Cd tolerance. Plant Cell Rep. 2018;37(11):1485-97.

45. Filipović-Trajković R, llić ZS, Šunić L, Andjelković S. The potential of different plant species for heavy metals accumulation and distribution. J Food Agric Environ. 2012;10:959-64.

46. Wang S, Wu W, Liu F, Liao R, Hu Y. Accumulation of heavy metals in soil-crop systems: a review for wheat and corn. Environ Sci Pollut Res. 2017;24(18):15209-25.

47. Youssef MA, Abd El-Gawad AM. Accumulation and translocation of heavy metals in eggplant (Solanum melongena L.) grown in a contaminated soil. J Energy Environ Chem Eng. 2018;3:9-18.

48. Kandziora-Ciupa M, Nadgórska-Socha A, Barczyk G, Ciepał R. Bioaccumulation of heavy metals and ecophysiological responses to heavy metal stress in selected populations of Vaccinium myrtillus L. and Vaccinium vitis-idaea L. Ecotoxicology. 2017;26(7):966-80.

49. Alagić SČ, Tošić SB, Dimitrijević MD, Antonijević MM, Nujkić MM. Assessment of the quality of polluted areas based on the content of heavy metals in different organs of the grapevine (Vitis vinifera) cv Tamjanika. Environ Sci Pollut Res. 2015;22(9):7155-75.

50. Shiyu QIN, Hongen LIU, Zhaojun NIE, Rengel Z, Wei GAO, Chang LI, et al. Toxicity of cadmium and its competition with mineral nutrients for uptake by plants: a review. Pedosphere. 2020;30(2):168-80.

51. Wang $M$, Yang $Y$, Chen W. Manganese, zinc, and $\mathrm{pH}$ affect cadmium accumulation in rice grain under field conditions in southern China. J Environ Qual. 2018;47(2):306-11.

52. Rahman A, Nahar K, Hasanuzzaman M, Fujita M. Manganese-induced cadmium stress tolerance in rice seedlings: Coordinated action of antioxidant defense, glyoxalase system and nutrient homeostasis. CR Biol. 2016;339(11-12):462-74.

53. He B-Y, Yu D-P, Chen Y, Shi J-L, Xia Y, Li Q-S, et al. Use of low-calcium cultivars to reduce cadmium uptake and accumulation in edible amaranth (Amaranthus mangostanus L.). Chemosphere. 2017;171:588-94.

54. Yang Y, Chen R, Fu G, Xiong J, Tao L. Phosphate deprivation decreases cadmium (Cd) uptake but enhances sensitivity to $C d$ by increasing iron (Fe) uptake and inhibiting phytochelatins synthesis in rice (Oryza sativa). Acta Physiol Plant. 2016;38(1):28.

55. Sasaki A, Yamaji N, Yokosho K, Ma JF. Nramp5 is a major transporter responsible for manganese and cadmium uptake in rice. Plant Cell. 2012;24(5):2155-67.

56. Österås $A H$, Greger M. Interactions between calcium and copper or cadmium in Norway spruce. Biol Plant. 2006;50(4):647.
57. Murtaza G, Javed W, Hussain A, Qadir M, Aslam M. Soil-applied zinc and copper suppress cadmium uptake and improve the performance of cereals and legumes. Int J Phytorem. 2017;19(2):199-206.

58. Ming H, Naidu R, Sarkar B, Lamb DT, Liu Y, Megharaj M, et al. Competitive sorption of cadmium and zinc in contrasting soils. Geoderma. 2016;268:60-8.

59. Mohammad A, Moheman A. The effects of cadmium and zinc interactions on the accumulation and tissue distribution of cadmium and zinc in tomato (Lycopersicon esculentum Mill.). Arch Agron Soil Sci. 2010;56(5):551-61.

60. Qiu R-L, Thangavel P, Hu P-J, Senthilkumar P, Ying R-R, Tang Y-T. Interaction of cadmium and zinc on accumulation and sub-cellular distribution in leaves of hyperaccumulator Potentilla griffithii. J Hazard Mater. 2011;186(2-3):1425-30.

61. Abdu N, Abdullahi AA, Abdulkadir A. Heavy metals and soil microbes. Environ Chem Lett. 2017;15(1):65-84.

62. Vohník M, Pánek M, Fehrer J, Selosse M-A. Experimental evidence of ericoid mycorrhizal potential within Serendipitaceae (Sebacinales). Mycorrhiza. 2016;26(8):831-46.

63. Pasqualetti M, Mulas B, Canzonetti G, Benedetti A, Tempesta S. Effects of long-term heavy metal contamination on soil fungi in the Mediterranean area. Cryptogam Mycol. 2012;33(1):43-57.

64. Likar M, Regvar M. Arbuscular mycorrhizal fungi and dark septate endophytes in grapevine: the potential for sustainable viticulture? MycorrhizaFunction, Diversity, State Art. 2017;275-89.

65. Cantor A, Hale A, Aaron J, Traw MB, Kalisz S. Low allelochemical concentrations detected in garlic mustard-invaded forest soils inhibit fungal growth and AMF spore germination. Biol Invasions. 2011;13(12):3015-25.

66. Ghosh S. Fungi-mediated detoxification of heavy metals. Recent Adv Bio Metal Contami. 2021;205-19.

67. Hujslová M, Gryndler M. Fungi in biofilms of highly acidic soils. Fungi Extreme Envir: Ecolo Role Biotech Significance. 2019;185-203.

68. Nam I-H, Murugesan K, Ryu J, Kim JH. Arsenic (As) removal using Talaromyces sp. KM-31 isolated from as-contaminated mine soil. Minerals. 2019;9(10):568

69. Blinda A, Koch B, Ramanjulu S, Dietz KJ. De novo synthesis and accumulation of apoplastic proteins in leaves of heavy metal-exposed barley seedlings. Plant Cell Environ. 1997;20(8):969-81.

70. Kumar K, Raina SK, Sultan SM. Arabidopsis MAPK signaling pathways and their cross talks in abiotic stress response. J Plant Biochem Biotechnol. 2020;29:700-14. https://doi.org/10.1007/s13562-020-00596-3.

71. Huang X, Duan S, Wu Q, Yu M, Shabala S. Reducing cadmium accumulation in plants: structure-function relations and tissue-specific operation of transporters in the spotlight. Plants. 2020;9(2):223.

72. Borghi L, Kang J, Ko D, Lee Y, Martinoia E. The role of ABCG-type $A B C$ transporters in phytohormone transport. Biochem Soc Trans. 2015;43(5):924-30.

\section{Publisher's Note}

Springer Nature remains neutral with regard to jurisdictional claims in published maps and institutional affiliations.

Ready to submit your research? Choose BMC and benefit from

- fast, convenient online submission

- thorough peer review by experienced researchers in your field

- rapid publication on acceptance

- support for research data, including large and complex data types

- gold Open Access which fosters wider collaboration and increased citations

- maximum visibility for your research: over 100M website views per year

At BMC, research is always in progress.

Learn more biomedcentral.com/submissions 